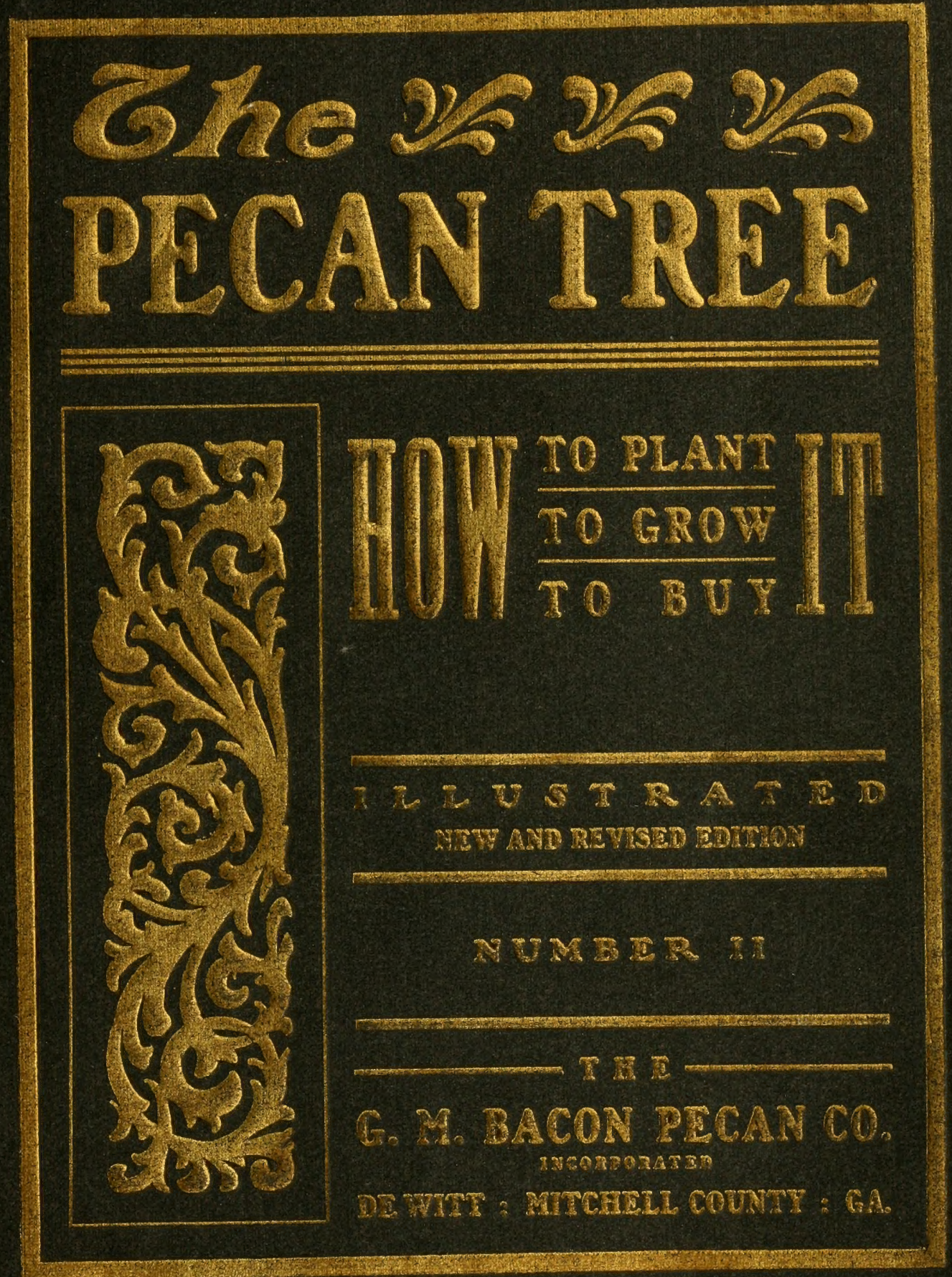




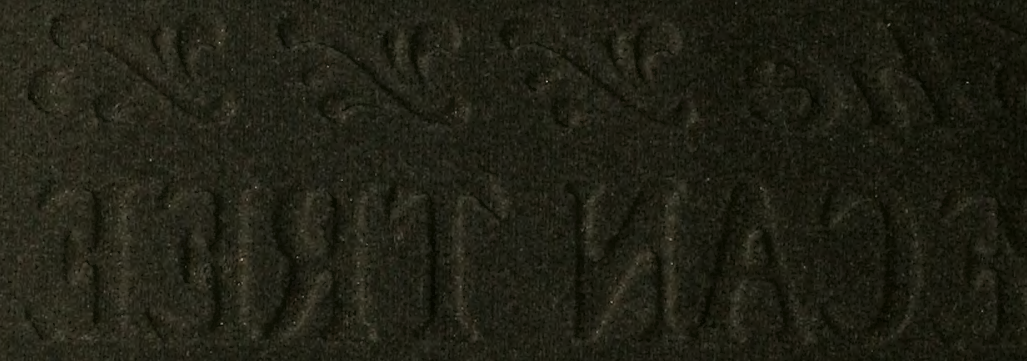
(11) $10 \% 278$
(1)
(1)
(X) 8 ,
110
(1) $11,(1) 1$

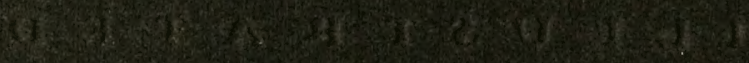

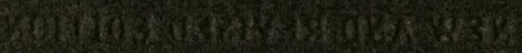

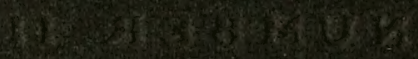

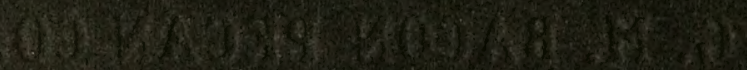
Wongon:

bis y y 


\title{
ILLUSTRATED
}

\section{CATALOGUE AND PRICE-LIST}

OF

\author{
GRAFTED, BUDDED AND SEEDLING
}

PAPER-SHELL PECANS

AND

OTHER NUT-BEARING TREES

WITH WHICH IS INCORPORAT ED A TREATISE ON

PECAN CULTURE

No. II.

O F F I C E R S

G. M. BACON, Préfident. DE Wit'T C. BACON, First Vice-President. HERBERT C WHITE, SECOND VICE-PRESIDENT AND HORTICULTURIST.

J. P. GIIL, ThiRd VICE-President. MILTON BACON, SECretary and Treasurer.

THE G. M. BACON PECAN COMPANY DE WITT, MITCHELL COUNTY, GEORGIA 


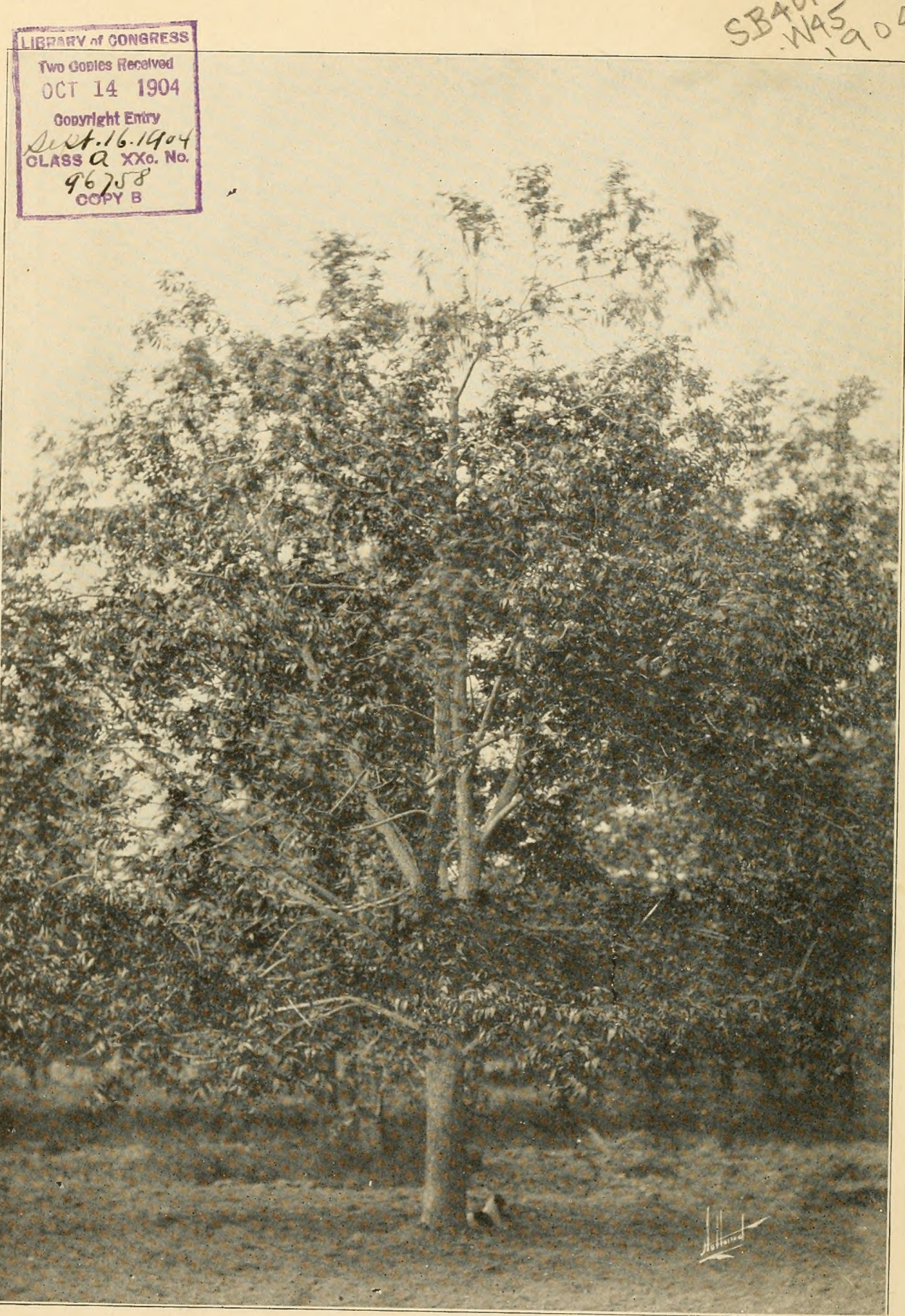

The parent "Georgia Giant' tree at DeWitt, Georgia. Planted in 1886. Began bearing when five years old and has produced heavy annual crops every year since. Top of tree has been severely cut back to obtain budding and grafting wood. 


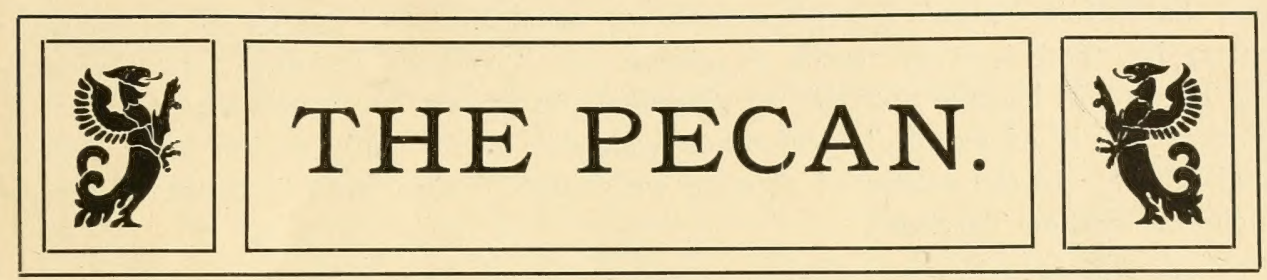

(Hicoria Pecan, (Marsh), Britton; Carya olivaeformis, Nuttall).

Introductory.-The inauguration of any great, permanent and far-reaching industry, (like the Pecan) has always been attended with much patient pioneering and experimental work, with the concomitant losses and disappointments incident, and prior to, its establishment upon a safe and profitable basis. This is the history of all the great commercial (including agricultural and horticultural) successes of to-day, and it is only as a result of the faithful, intelligent and well-directed efforts of a comparatively few investigators that experimental stages with the Pecan have been passed and that it is to-day a full-fledged industry, established upon a firm, sure and safe basis.

Descriptive. - The Pecan is one of, and by far the most valuable and important species of the genus Hicoria, the shagbark (H. Ovata), the shellbark ( $H$. Laciniosa), and one or two sweet-meated and thin-shelled (very rare) varieties of the pig nut (H. Glabra) following in pomological importance. There are, however, two or three most promising large thin-shelled hybrids, (supposedly cross-species of the Pecan and shagbark), now being tested by us, which will probably be of great utility and value for planting in the extreme North, Northwest and East, where, although the Pecan will grow, it does not usually produce the extremely large and thin-shelled nuts as in the middle and lower South. The Pecan grows to be one of the largest and most majestic of trees. The Pecan lives to an indefinite age, trees having been cut down in Texas plainly indicating a 500-year growth.

Range of Culture.-The Twelfth Census reported bearing Pecan trees in twenty-two States as follows: Alabama, Arizona, Arkansas, California, Florida, Georgia, Illinois, Indiana, Kansas, Kentucky, Louisiana, Maryland, Mississippi, Missouri, New Mexico, North Carolina, South Carolina, Oklahoma, Tennessee, Texas, Virginia, Washington, also in Indian Territory. The next census will doubtless report bearing Pecans in many more States. The Pecan is the only nut capable of successful culture over such a vast area of country and it is for this reason that in a Bulletin published by the Government in 1896 , it is said "the 
Pecan is probably destined to become the leading nut of the American market" and that "If its culture is pushed with the usual skill and energy of American enterprise, there is every reason to believe that it will not be many years before the Pecan will become not only an abundant nut in our markets, but also an important article of export." Reference was, of course, made to the large thinshelled nut. In the season of I903-04 we shipped Pecan trees to twenty States, including Indian Territory.

An Important Industry. - Increasing and more intelligent attention is being given each year to the planting and cultivation of the Pecan. The permanent and increasing annual value of the tree is ralized. Experimental stages

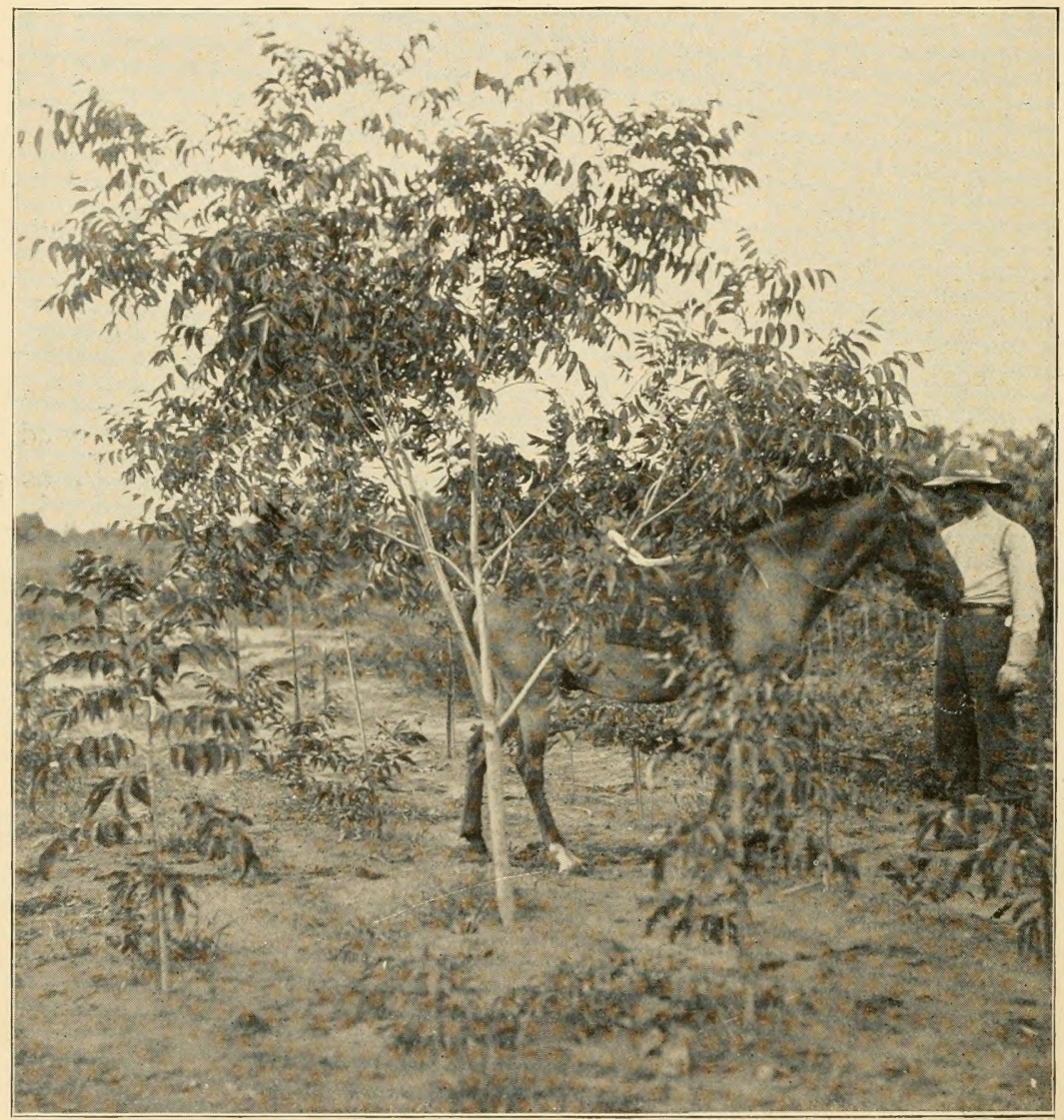

FOUR-YEAR-OLD "GEORGIA GIANT" GRAFTED TREE. HEIGHT OF TREE, 11 FEET. SPREAD OF BRANCHES, $91 / 2$ FEET. TREE IN BEARING. DEWITT, GA. 
have been passed and the outlook for the industry is brighter than ever. The demand for fine nuts for table and confectionery purposes is constant, and the supply of fine nuts is entirely inadequate.

Easy to Market. - There is an annually increasing demand for Pecan nuts, none that we know of being produced on the eastern hemisphere. Pecan nuts do not have to be forced on the markets. They can be held for a considerable length of time, the market watched, and the nuts placed on sale when the best price can be commanded. They may be kept in perfect condition, in cold storage, from one season to another.

Soils. - We have Pecan trees planted on rich river bottoms, on stiff red clay, on deep sand hills, on pebbly soil, on sandy loam underlaid with clay, as well as on stiff hard soil, largely fire and pipe clay (which cracks and bakes in dry weather), but we find the Pecan thrives on all. Soils continuously boggy or springy should be avoided, unless capable of surface drainage. Occasional overflows do not hurt the Pecan. Some of our best trees are subject to the overflow of the Flint River, and although they have stood several feet in the water for fifteen days at a time they are as vigorous and as heavy annual bearers as others. The wild Pecan trees of Texas are also found along rivers subject to overflow, the nuts no doubt being carried by freshets and deposited on overflowed land. For this reason the fact that wild Pecans are only found on river bottoms gives rise for the wrong impression that they will only succeed on bottom lands, for they will thrive in practically all soils.

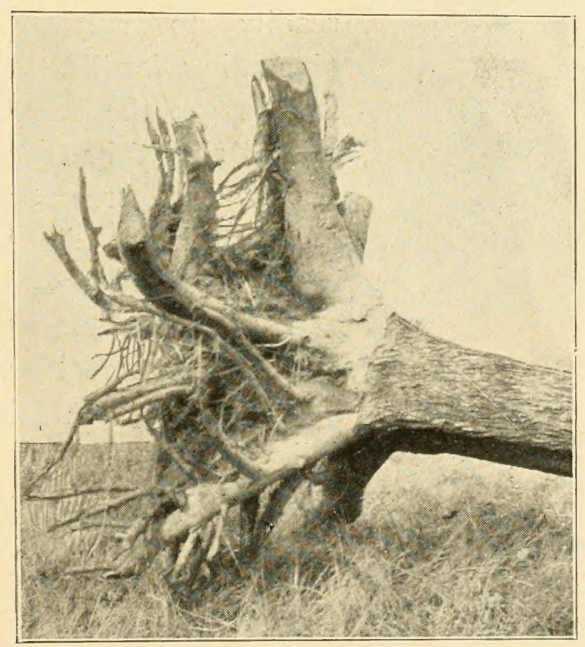
ROOT OF EIGHTEEN-YEAR-OLD PECAN TREK,
SHOWING ENTIRE TAP-ROOT, SUCCESSFULLY TRANSPLANTED IN 1904.
The Pecan adapts Itself to Many Conditions-The Pecan is an extremely hardy tree, is easily transplanted and adapts itself to very variable soil and climatic conditions. Where trees are planted on land with a very wet subsoil, the tap-root ceases to grow after reaching a stratum where there is a sufficient supply of water; on the other hand, new tap-roots quickly grow where more moisture is temporarily needed. Many Pecan trees, with good lateral root systems, even in dry soils, have very little tap-root. We have dug up and successfully transplanted several eighteen-yearold Pecan trees, and have found the taproots not over four feet long. (See illustration). 
Quality of Nuts. - There is a great difference in the quality and market value of Pecan nuts. Some are small, thick-shelled and of poor quality. The best nuts are of medium

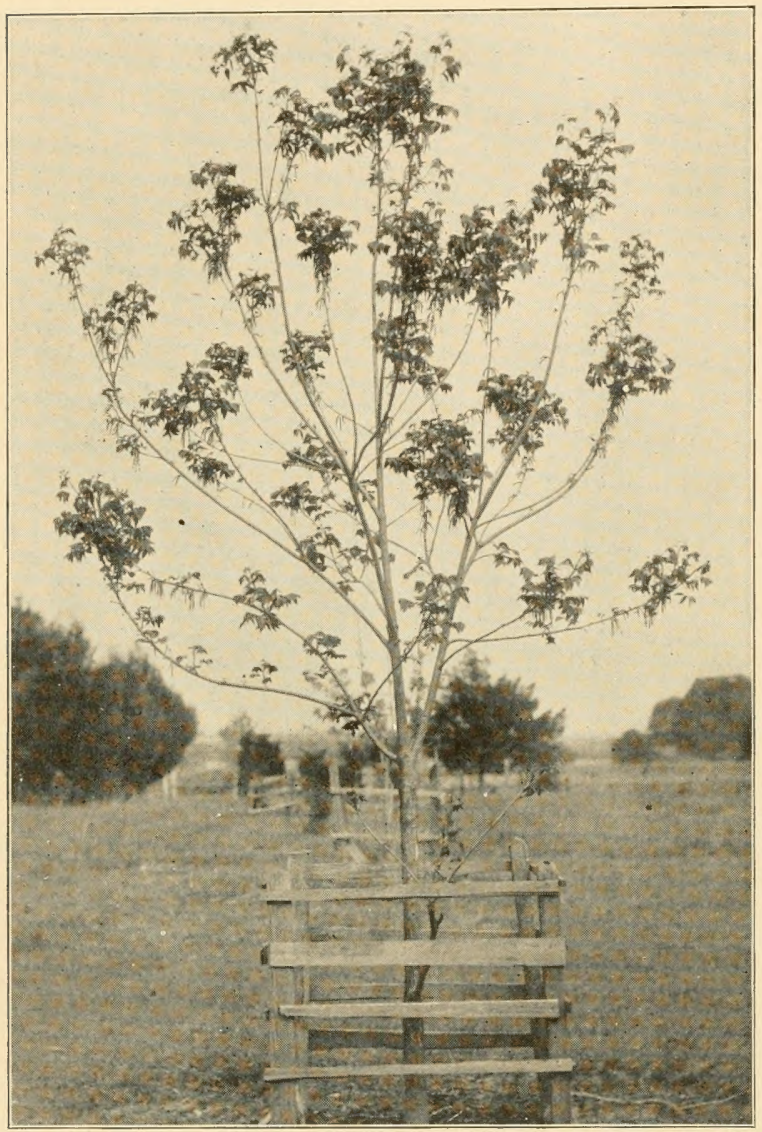

HEAVY BLOOMING OF FOUR-YEAR-OLD BUDDED PECAN TREE, AT DEWITT, GEORgIA. THE PENDULOUS TASSELS ALONG THE TWIGS AND BRANCHES ARE THE MALE (STAMINATE) BIOOMS. to large size, with thin shells, well filled, of good keeping qualities, and delicious flavor. Only varieties combining these qualities are being propagated by this Company.

Profits. - The profits in Pecan growing, like those in stock raising, fruit growing and other analogous industries, depend almost entirely upon the kind of Pecan trees planted, the quality of stock raised, the varieties of fruit trees planted and the care taken of them. The Pecan is a tree which responds readily to cultivation, (including fertilization), and to get the best results it should be treated as a fruit tree from "seed to harvest." We have found that the parental characteristics of early, annual and heavy bearing are faithfully transmitted by budding and grafting.

We have three-year-old budded and grafted trees with every terminal twig carrying from two to eight nuts, (in other words, bearing to their utmost capacity, for a Pecan does not bear nuts other than on its terminal growth), which a number of our valued customers have visited us to see. We have also two-year-old buds and grafts on just five-year-old seedling stocks, carrying as high as ten pounds of 
nuts, (the seedlings being budded and grafted when three years old and being ' once moved and transplanted from nursery when one year old). By budding and grafting all our nursery stock on three-year seedling stocks and roots, as we are

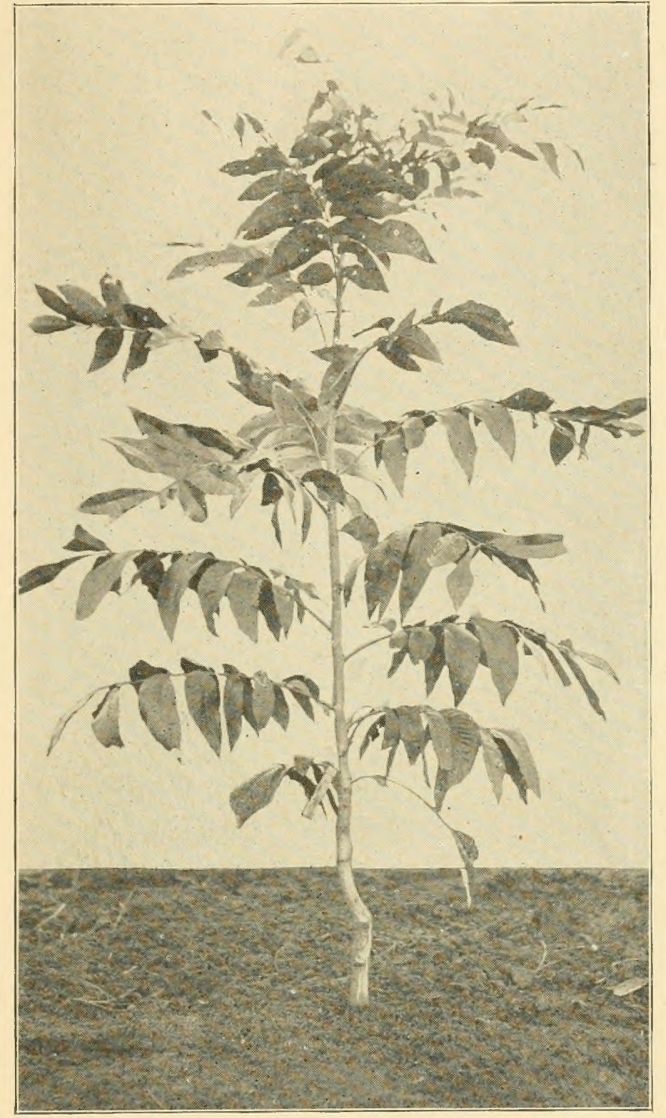

BUDDED TREE SHOWING UNION OF BUD WITH SEEDLING STOCK. now doing (contrary to the usual practice among growers), it will be observed that such trees will be eight years old the fifth year from transplantation. At eight years of age our parent Georgia Giant tree (a rare seedling) bore fifteen pounds of nuts. Assuming, therefore, that prolific and early bearing varieties (and there are a number), with threeyear roots to commence with, be planted and properly cared for (a comparatively simple and inexpensive matter), the average yield per tree the fifth year from transplantation may run as high as ten pounds, the sixth year to fifteen pounds, the seventh year to twenty-five pounds and over, and so on until the tenth year from setting out, when a yield of from fifty to one hundred and fifty pounds may reasonably be assumed. Small mixed nuts will net the grower from 5 to I2 I-2 cents per pound, increasing in value according to size and quality to 40 cents per pound and upwards. Selected specimens are sold for planting at prices ranging from 50 cents to $\$ 3.00$ per pound. It must always be remembered that it is as easy to raise the fine varieties as the common nuts.

The bearing of seedling trees is so variable that the yields of seedling groves of to-day are absolutely no criterion to go by, but when uniform groves of definite, early, annual and heavy-bearing varieties can now be planted, it will quickly be seen that the yields of the future must be enormously greater. Abundant proof of this exists wherever tried.

Importation of Nuts. - In Report No. 15 of the U. S. Bureau of Statistics, being a compilation of the quantities and values of imported merchandise entered for consumption in the United States during the years I9OI and 1902, it will b. 
found that in 1901 , nuts to the value of $\$ 3,756, \mathrm{I} 37.04$ were imported, and that for the year ending the 3 oth of June, I902, the stupendous sum of $\$ 4,214,676$. I7 was sent out of this country for nuts. By the time freight, insurance, duties and the profits of wholesalers and retailers are added, it will be seen that the nut eating public of the United States are spending annually fully $\$ 10,000,000.00$ for nuts raised in foreign countries alone. The value of imported nuts in 1895 was $\$ 2,012,844$ (U. S. Year Book, I898), increasing to $\$ 4,214,676.17$ in I902. In I901 the duties alone on imported nuts were \$922,9I6.II, and in I902 \$I,280,6I5.72. Such figures must convince the most skeptical of the opportunities in planting Pecans. The tariff on nuts ranges from half a cent per pound on unshelled peanuts to six cents a pound on clear shelled almonds. The only nuts on the "free list" are cocoanuts, cream and Brazil, olive nuts ground, and palm and palm nut kernels.

Nut Oil.-Vast possibilities also lie with Pecan nuts in this respect. The U. S. Bureau of Statistics furnishes the information that in I901, 365,747 gallons of Nut Oil were imported, valued at ports of entry in the sum of $\$ 169,892$. In 1902 the demand had increased to such an extent that 405,02 I gallons were imported, valued at $\$ \mathrm{I} 77$, I 45 . In the face of these government figures on importations, both as to Nuts and Nut Oil, it is idle to say that there is not a field of the greatest possibilities in Nut Culture, and particularly with the Pecan.

Exportations. - In 1902, nuts to the value of only $\$ 304,241.00$ were exported, $\$ 75,25$ I.00 going into the Dominion of Canada (Nova Scotia, New Brunswick, Quebec, Ontario, Manitoba, etc.), where the Pecan can not be profitably grown. The remainder in minor quantities going to European, North American, South American, Asian, Oceanian and African countries.

Ornamental as Well as Valuable. - We can not too earnestly recommend the planting of the Pecan for shade and ornamental purposes instead of (from a food-producing point of view) valueless oaks, poplars, sycamores, elms, maples, etc. The Pecan will outlive all these, and make a far handsomer tree. Two or three Pecan trees, even one tree, will in a few years yield revenue enough to pay taxes on a very valuable city lot. For this purpose we always keep several thousand extra large three and four-year-old trees, running from six to eight feet high, on hand, and are prepared to quote prices on these extra large trees. They are ideal for planting on lots, streets and around residences, where both quick shade and early bearing are desired.

Marketing. - There are many thousands of people in the South and all over the country who have never even seen any of the choice nuts now being grown, let alone eaten any, for they are rarely sold at a price at which the ordinary person can afford to eat them. These fine nuts are as easily grown as the small ones. Persons starting into Pecan culture now can do so with a certainty of success if they will 


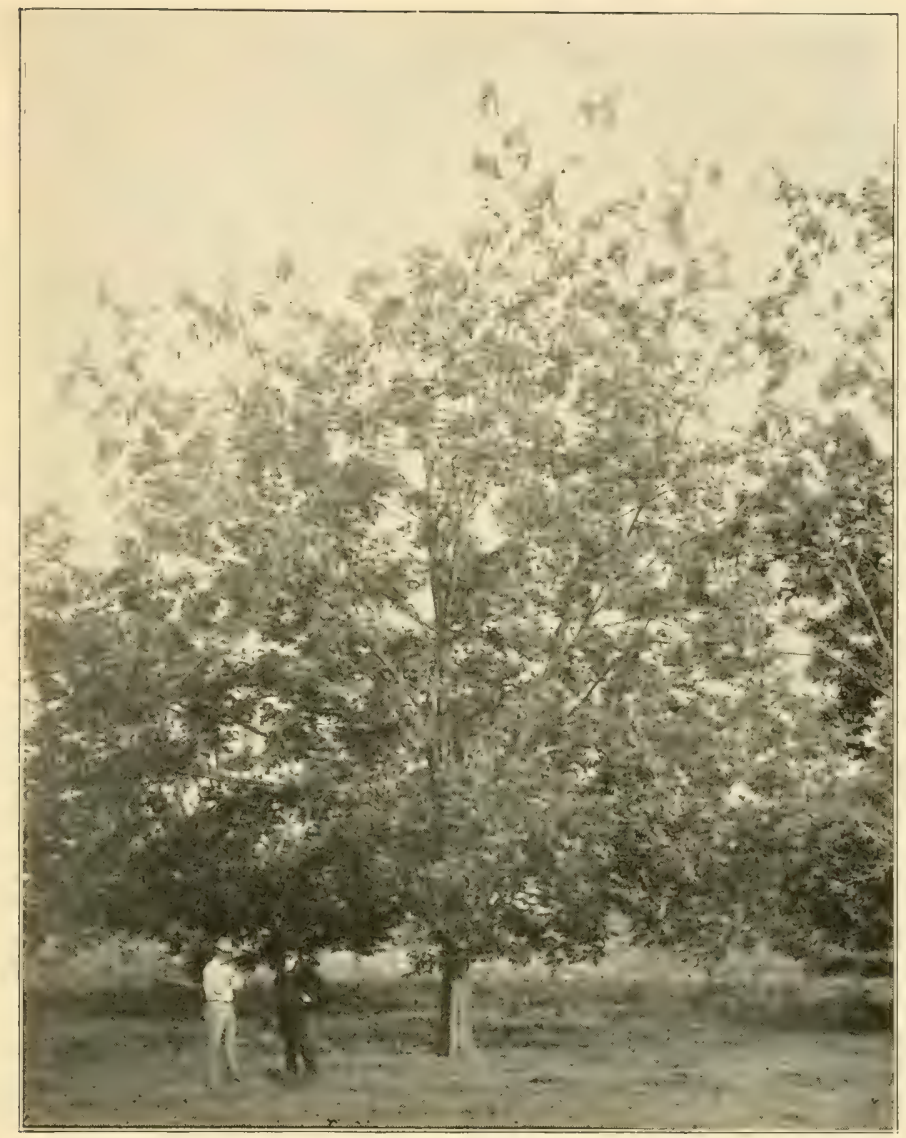

THE PARENT "SENATOR" TREE. SIXTEEN YEARS OLD. RAISED IN NURSERY AND SET OUT WHEN ONE YEAR OF AGE. SPREAD OF LINIBS, 45 FEET. HEIGHT, 65 FEET. DEWITT, GEORGIA. buy good trees. When we started planting Pecan trees we bought anything we could gat (as many are doing now), and we have in our/seedling groves treés producing nuts of all shapes and sizes; but we have trees, heavy annual bearers, producing nuts unexcelled in all good qualities, and it is only from these trees that we are propagating. The experience we now have would have been of inestimable worth to us twenty years ago, but the planter of today need not take any chances, if he will plant good trees and take care of them.

\section{Age of Bearing}

-We have a few seedling trees which bore nuts at five years (notably the Georgia

Giant). This with seedlings is exceptional and can not be relied upon. A larger number of seedling trees, however, came into bearing at six years, and many at seven. We have no seedling trees that have not borne in nine years, many bearing profitable crops from six years upwards. The subject of age of bearing is more fully discussed under budding and grafting. The most impossible stories are told by irresponsible and dishonest dealers upon this subject, many seedling trees having been guaranteed to bear in two years and to come true to seed. It is an ordinary occurrence for budded and grafted trees to begin to bear at two years and we have many which have borne fair crops of nuts at three years. 


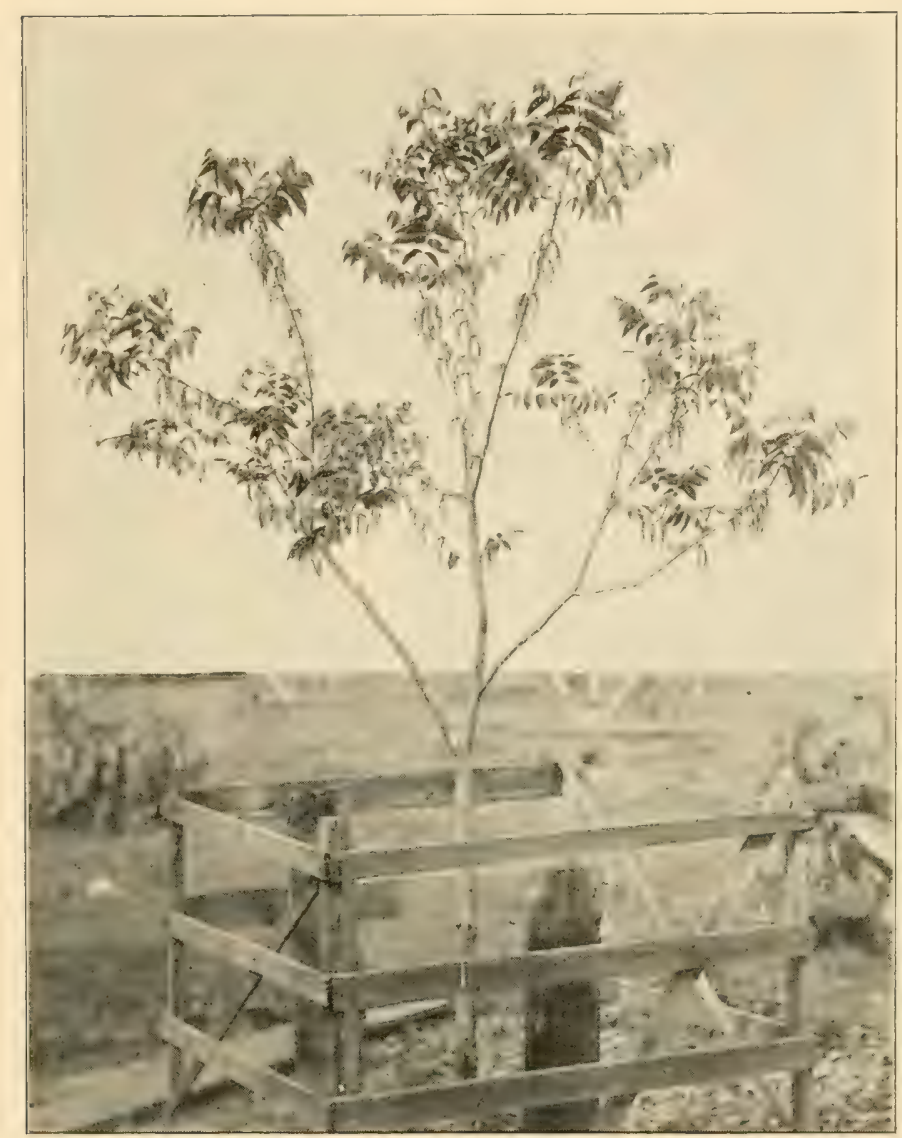

PROFUSE BLOOMING OF FOUR-YEAR-OLD GRAFTED PECAN TREE AT DEWITT, GEORGIA. THE DROOPING TASSELS ON THE LIMBS ARE THE CATKINS WIICI FURNISH THE POLLEN.
Few Enemies. -Persons who say that the Pecan is entirely free from insect enemies are in error-sometimes intentionally, so m etimes from inexperience or ignorance. However, the Pecan tree, of all valuable food-producing trees, is attacked by fewer insects or fungous diseases than almost any other. Owing to its nature and strong vitality, injuries made by insects seldom effect a permanent disablement, for the only way to destroy a Pecan is to grub it up, even to its uttermost roots. In the case of the Pecan, profitable crops of fruit can be made with more certainty, with less expense, with less trouble from insects, and

with less worry than any other known valuable food-producing tree.

\section{AS TO PLANTING AND CULTIUATION.}

Inquiries. - We receive a great many inquiries regarding the setting out, care and cultivation of Pecan groves. As we give our personal attention to all the details of selection, propagation, packing, shipping, etc., we find it impossible. to always answer such inquiries by letter as fully as we would like and we have, therefore, embraced herein practically all the main and material points, including the selection of trees, their planting, fertilization and subsequent cultivation. If 
however, there is anything you wish to know not contained herein, kindly write us about it and we will take pleasure in advising you.

Plant $\mathcal{N u t s}$ or Trees? -We have planted nuts where we wanted trees

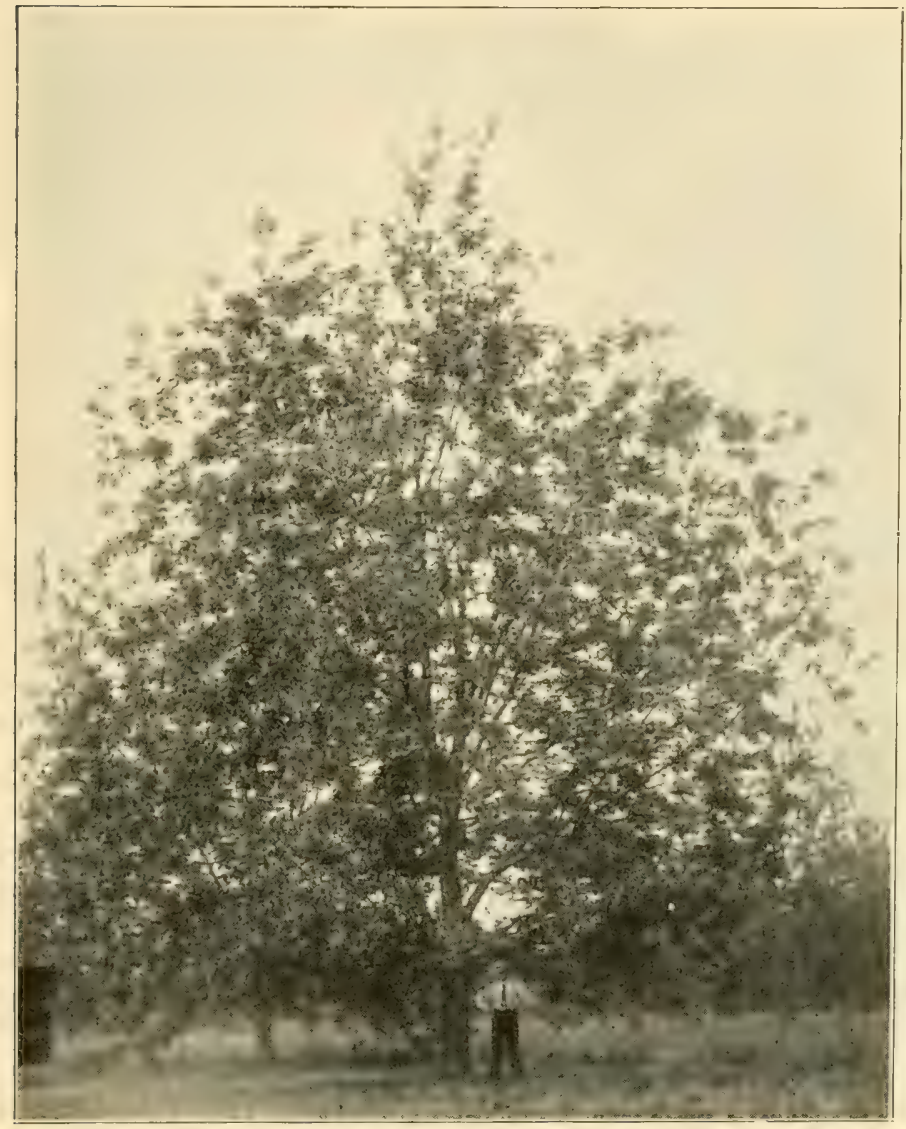

THE BACON'S CHOICE (SYN. "BACON") PARENT TREE. BORE 255 POUNDS OF NUTS IN 1903. EIGUTEEN YEARS OLD. TRANSPLANTED FROM NURSERY WHEN YOUNG. DEWITT, GEORGIA. to grow, but have entirely abandoned that method, as we have found that transplanting from a nursery is far preferable. When others have contended with the same difficulties we have, in the shape of field mice, squirrels, moles, salamanders, pigs, woodlice, ants, etc., and find themselves (after yearly replanting for five or six years) with a grove (?) of trees running from ten inches to twenty feet high, they will come to the same conclusion. It will pay to buy the young trees from a reliable grower rather than to try, without any experience, to raise your own trees. By the tir..: you figure in the time spent in getting a grove started, the cost of the seed, fertilizer, cultivation and percentage of losses in non-germination,it would have been better to have bought two, three or four-year-old trees all trimmed and ready for planting, gaining much time and have a grove of trees uniform in size and age. 
When to Plant. - In the Southern States, Pecan trees may be set out any time after the leaves

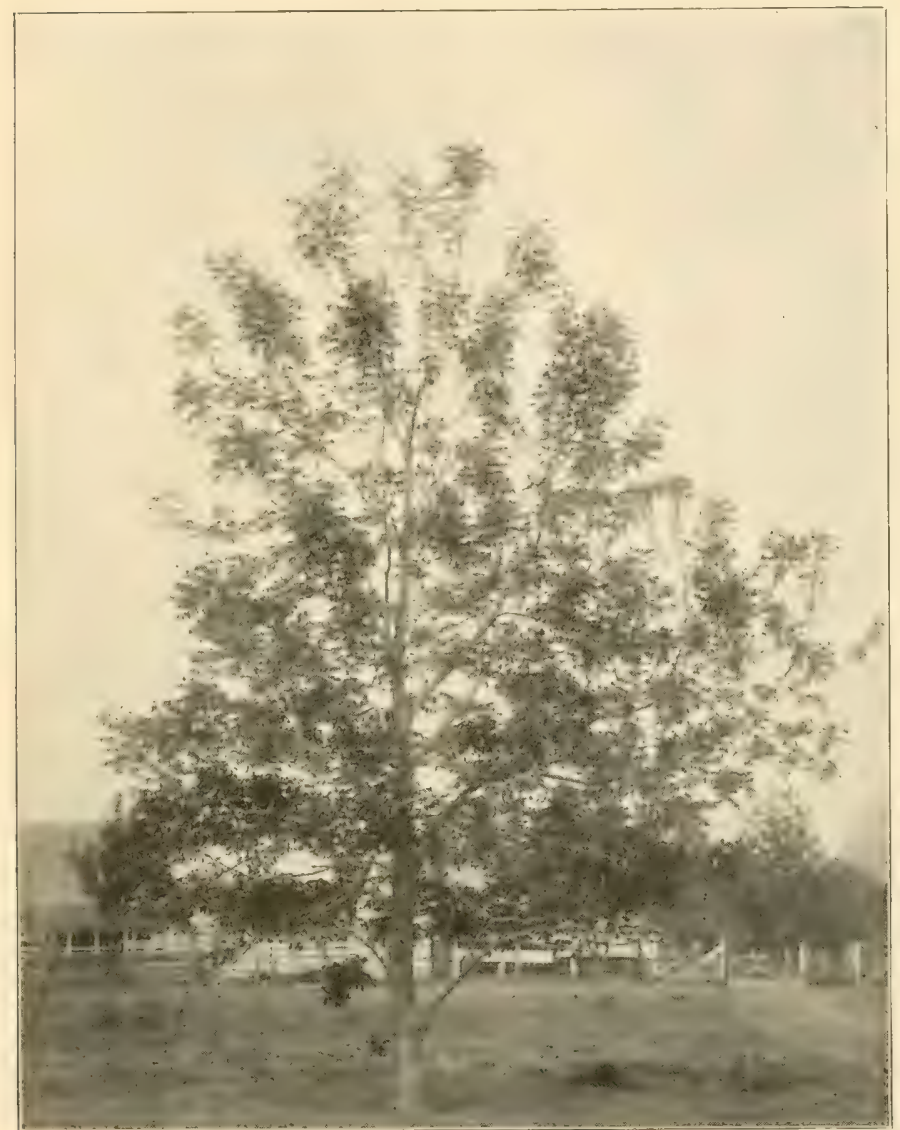

THE PARENT MAMMOTH (RENAMED "MoNARCH") TREe. APIL, 1904. TREE BLOOMING HEAVILY BUT FOLIAGE NOT FULIY DEVELOPED WHEN PHOTOGIAPHED. DEWITT, GEORGIA. drop in the fall (varying largely with the season, but nearly always by the first week in December), until generally the end of March. It is essential, however, that trees be dormant.

In the North: Northwest, Eastern and Middle States, above approximaltely the forty-first degree of latitude, north, the ground will frequently be frózen or snowbound by the time Southern-grown trees are perfectly dormant. Under these circumstances spring planting should be resorted to. Orders for trees where these conditions prevail should be made during the winter, and if shipped at time of order, they can be placed in cool storage until springtime, when ground is in a suitable condition for planting. Dormant trees may easily be kept many months in a cool cellar, with roots moistened occasionally and kept from exposure to frost, light or air.

"Some say to plant trees in the spring, And some say in the fall;

But the worst are those who compromise, And plant no trees at all.". 
Distance Apa,t. - Our plan was to plant $30 \times 30$ feet apart, or 48 trees to the acre. While this eventually becomes too close the trees will produce satisfactory and profitable crops of nuts for many years before it may become necessary to thin them out. Some even advocate planting $20 x 20$ feet, which gives one hundred and eight trees to the acre, and obtaining nuts from all for several years, when alternate rows may be moved and trees set elsewhere. In planting permanent groves to endure for generations, we prefer to set them from $40 \times 40$ to $50 \times 50$ feet.

Care of Trees Upon Arrival.-Upon arrival of shipment of trees, bundles should be opened, a trench dug in a shady place, and roots and half the tops of trees laid therein at a slope, covering them with damp earth and lightly watering. Trees may be kept in good condition several months in this way. At no time must roots be allowed to dry out, although an excess of moisture is not necessary. If trees are frozen upon arrival, bury the bundle without opening in cool moist earth, or let them thaw slowly in a cool cellar. If trees have dried out in transit, open bundle and bury trees completely for several days and they will resume a natural condition. Roots should be covered or wrapped up in wet sacking, moss or other material when taken to field for planting. Many trees are lost and nurserymen consequently blamed on account of failure of the planter to take this precaution.

We shipped one hundred large Pecan trees to the St. Lcuis Exposition, which arrived there frozen in a solid mass, but by gradually thawing them out, every tree recovered.

How to Set Out Pecan Trees.-In setting ont a Pecan tree, a hole 24 inches in diameter and 30 inches deep is usually large enough although wider holes may be dug with advantage. When setting out the tree, fill in with top soil, or woods arth. Well-rotted manure or good commercial fertilizer may be put in outer sides of hole, an inch or two beyond lateral roots while hole is being filled, but so as not to come in direct contact with the roots. Work and firmly press the dirt among the roots, laying each root out in a natural position. No holes or cavities in the soil should be left and soil must be in close contact with all roots, especially the tap-root. The tree should be set at such a depth that after a copious watering and the permanent settlement of the earth, it will be the same depth or perhaps a little deeper than it stood in the nursery row. It is very important that no part of the crown or root be left exposed to the air. It is better to plant them an inch or two deeper than they stood in the nursery than to have the crown of root exposed. The roots of Pecan trees are of a reddish brown color, which color may usually be noticed for several inches above where first roots. start. All that portion of tree showing any reddish brown tint should be under ground and never allowed to 
become exposed. The land should be plowed deeply and harrowed either previous to planting or soon afterwards. It is better to do this before planting, as trees may be disturbed by ploughing after planting. If tap-roots are inconveniently long, say over 30 inches, they may be cut off by a sloping cut with a sharp knife. All broken roots should be cut off. The foolish theory about a Pecan tree not bearing if its tap-root has been cut has been so universally disproved by ourselves and others that it is not worth discussion. If the taproot is cut when the tree is dug, as is often necessary, the cut quickly heals

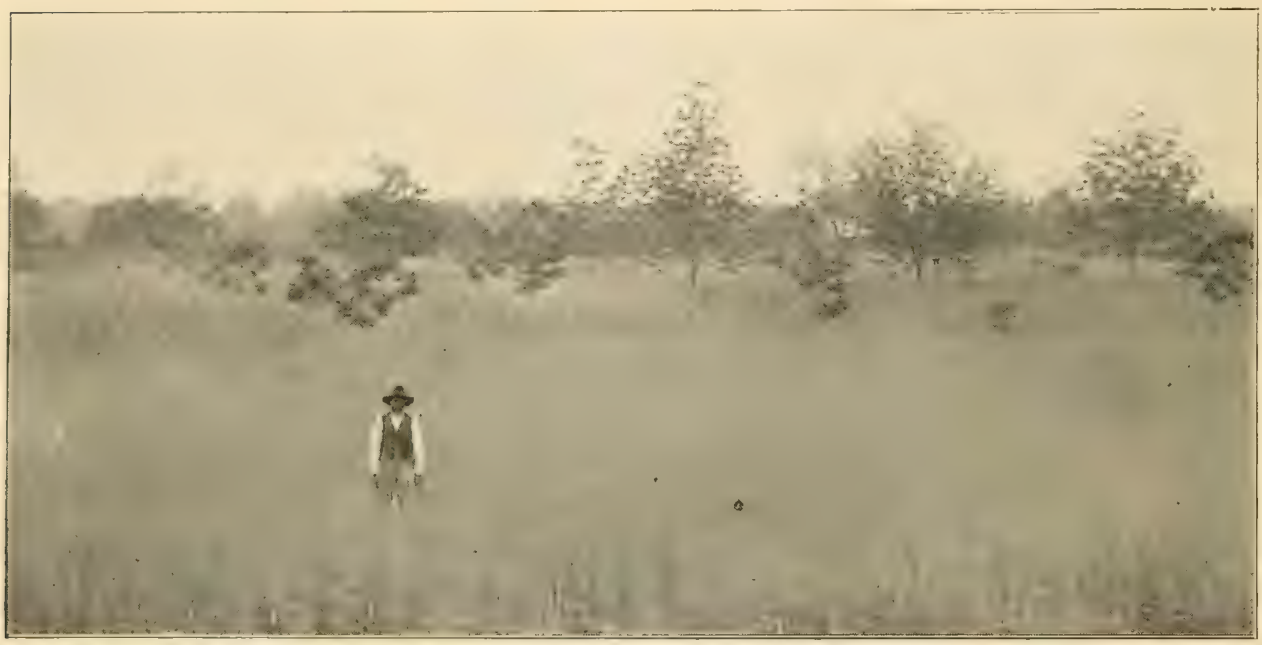

PECAN GROVE IN RYE, DEWITT, GA, CROPS OF ALL KIXDS MAY BE IRASED AMIONG TREES FOI? MANY TEARS.

over and a new tap-root is formed, if the trees needs it, which is not-always the case. White ants (tcrmites) occasionally attack the roots of newly set trees. Care should be taken to see that no pieces of wood or other debris upon which insects, their eggs or larvae might gain admittance to bottom of hole be contained in the soil in setting out trees. The dangers from insect attacks is so slight that it need not be seriously considered.

Fertilizers. - Well-rotted barnyard manure contains practically all the plant-food needed by a young Pecan tree. As it is difficult to get this in very large quantities, as a substitute we advise the use of some well-balanced highgrade fruit tree fertilizer, such as "White's Nut and Peach Grower, No. 2." After a tree has bloomed the first time, highly ammoniated or nitrogenous fertilizers, such as stable manure, cottonseed-meal, fish, blood, tankage, etc., should not be solely used, but potash and phosphoric acid in any of their 


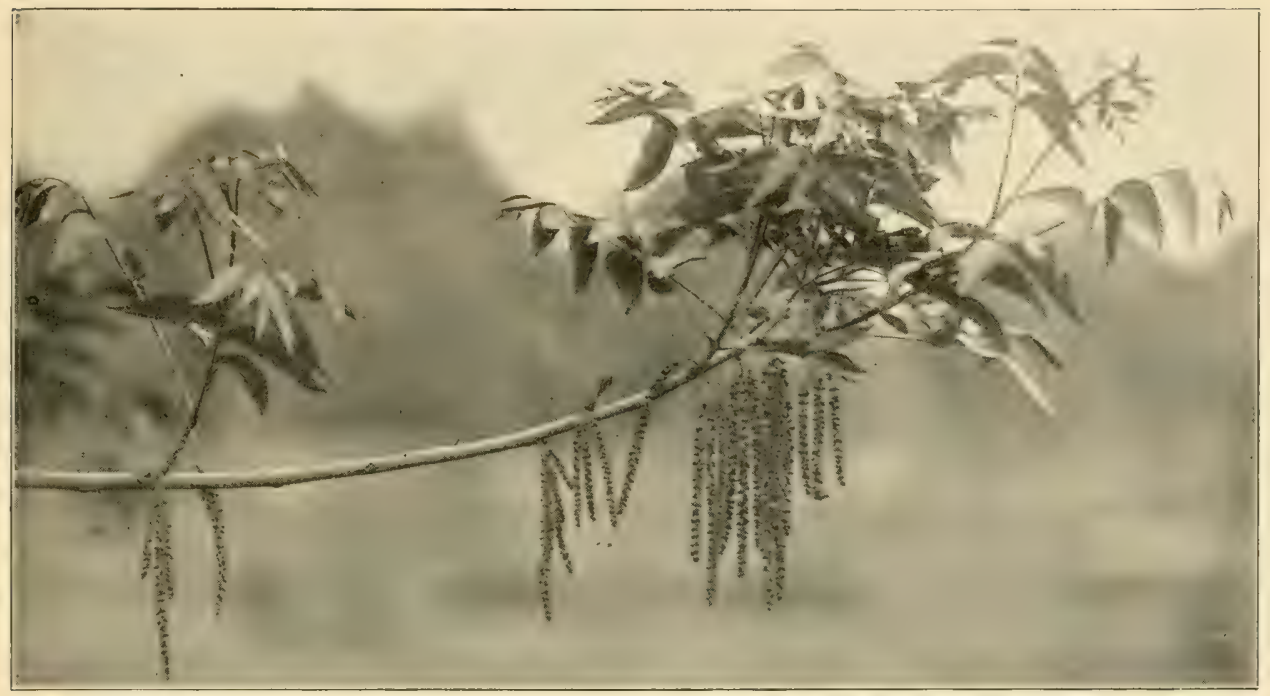

THE STAMINATE (MALE) BLOOM OF THE PECAN. A BRANCH OF AN 18-MONTH-OLD GEORGIA GIANT BUD ON A 4-YEAR-SEEDLING AT DEIVITT, GA. PHOTO. TAKEN APRIL, 1904. SEE FoLLOWING PICTURE SHOWING SAME BRANCII TAKEN IN SEPTEMBER, 1904.

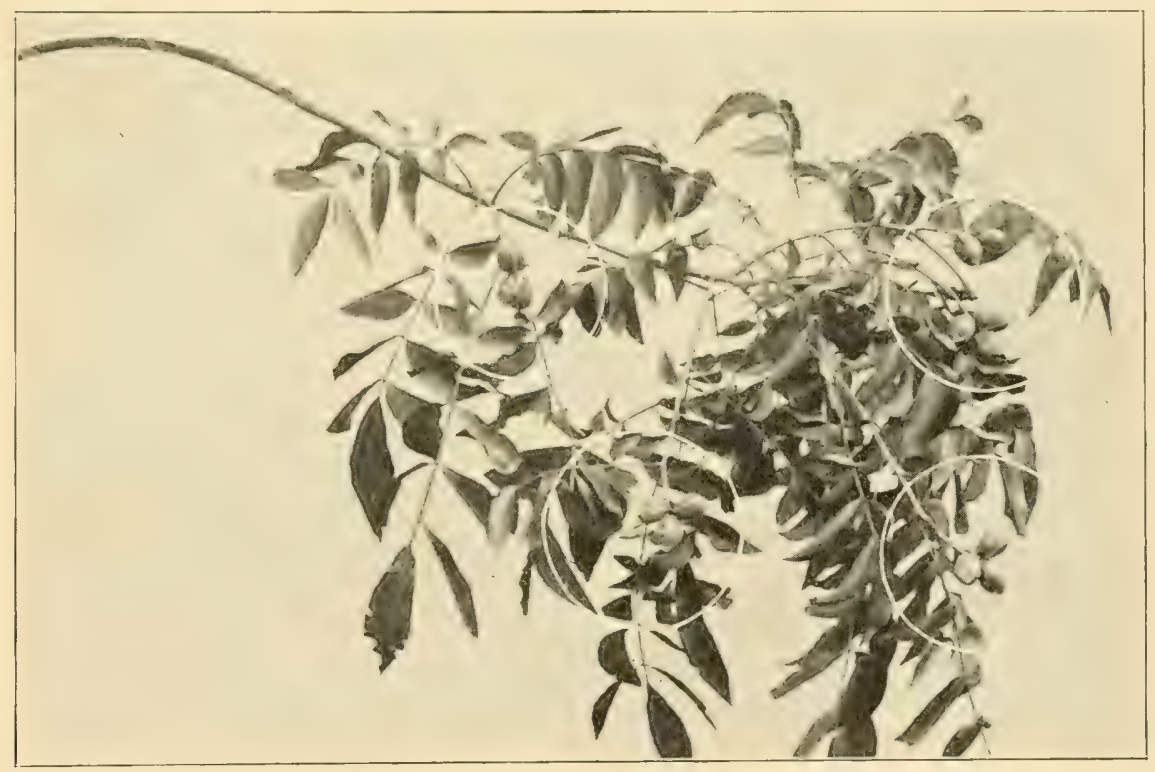

SAME BRANCI (SEPT. 1904) SHOWING 15 NUTS (WITHIN CIRCLES). 
respective forms should be added to induce bearing, although many trees will bear, no matter what they are fed on. Nitrogenous fertilizers cause a rapid growth, and while the tree is young and small it is as well to encourage as much healthy growth as possible, so that when it gets to be about five years old it will have a large top. Fertilizers should be broadcast and well-worked into the soil around the tree, commencing at a radius of about the extremities of the branches after the first year. The application of fertilizers too near the tree causes a congestion of roots and is likely to injure them.

Culture.-In Pecan groves, low-growing crops, such as peas, melons, cantaloupes, potatoes, peanuts, cotton, truck, etc., may profitably be planted. The land should be plowed and harrowed early in the spring and again in the fall. If sown in peas the hay cut from same more than pays all fertilizing and cultural expenses. Young trees should be kept free from grass and weeds, and occasional deep hoeings and thorough pulverization of the soil for several feet around the tree during the growing season are highly beneficial. Traes of all sizes, and especially newly-set ones, may be mulched with leaves, straw, dead weeds, etc.; to great advantage, conserving soil moisture, reducing expense in hoeing and affording a slowly-decaying supply of natural plant-food.

Uarieties.-Most Pecan trees are bisexual, but in planting a Pecan grove it is not always advisable to have only one variety. Where two or three varieties are planted, it is considered better to alternate several rows of each. The staminate (male) bloom which furnishes the pollen is produced on the wood of the previous season's growth, also at the point from where the new growth starts, and the pistillate (female) bloom, from which the nut is formed, is produced on the end of the new growth when it has grown from three to ten inches and over. It will occasionally happen that the male blooms (catkins) mature and release their pollen before the female bloom is sufficiently developed to be pollenated, or heavy rains will wash the pollen from the catkins at a time when pistillate bloom is in the right condition for pollenation. Without pollenation the female bloom withers and dies, or produces nuts without meat or only partially filled. Potent pollen is a sine qua non in a nut or fruit orchard. The pollen of Pecans is a yellow, fine, dustlike substance and is capable of being carried by air currents a great distance. Insects also are important factors in the pollenation of Pecan blooms. Potent pollen from one Pecan or allied species is fully as efficacious in fertilizing the female blooms of another tree of the same genus as it is its own, hence the frequent hybridization and cross-pollenation of one 
species with another, with the resulting lack of certainty of a seedling tree reproducing identically the nut from which it is grown. The product may be better or inferior, for there is no telling what took place at the time of impregnation. Opinion upon the subject of the percentage of nuts coming true to seed is very variable, but in our long experience we do not know of a single instance.

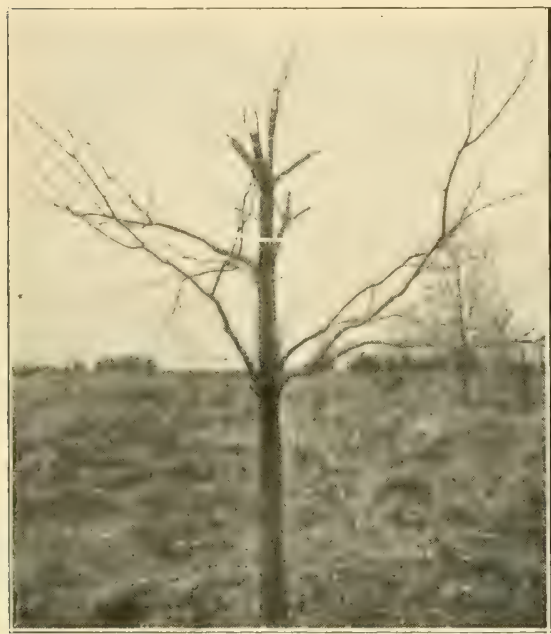

1

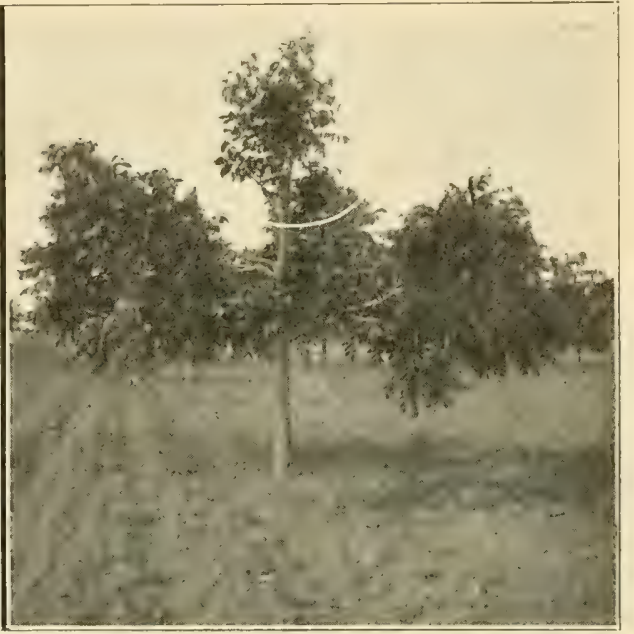

2

MFTHOD OF TOP GRAFTING LARGE TREES.

(1) DORMANT SCTONS (FEBRUARY.)

(2) GROWING SCIONS (MAY.) TIIE LOWER SEEDLIF BRANCHES ARE CUT OFF AFTER GRAFTS ARE WELL UNITED.

Results are the Same.-IVe have so many inquiries as to the difference between a budded and a grafted tree that to save correspondence will here say that, so far as results are concerned, there is no difference. A budded tree will bear as soon as a grafted tree, and vice versa. Grafting is done in the winter and spring months, by the cleft, whip and straddle methods, while scions are perfectly dormant. Budding is done in the summer and fall by the annular, patch or veneer methods, when sap is flowing freely and bark will slip. The mechanical operations of grafting and budding are entirely different, but a budded tree is just as desirable as a grafted one. Neither the grafting nor budding seasons are respectively long enough for extensive propagators to get all their work done, hence some trees being budded and others grafted. We therefore reserve the right to ship either budded or grafted trees, according to our stock of each kind. 
Budded and Grafted Trees Compared With Seedlings.-Grafted and budded trees have advantages over seedlings because (I) they usually begin to bear much earlier than seedlings; (2) they reproduce the variety from which buds and grafts were taken; (3) perpetuation of the early, heavy and annual bearing characteristics of the parent tree is obtained; (4) the greater care and attention usually given them on account of their greater cost.

Cost of Budded and Grafted Trees.-As a consequence of the variable success attending the propagation of Pecans by budding and grafting and the comparative slowness of the processes as compared with the simpler propagation of peaches, plums, oranges, apples, etc., the trees must necessarily sell at a price which allows a margin to cover. (I) great losses, occasionally, in budding and grafting from unfavorable weather, such as prolonged droughts, or excessive

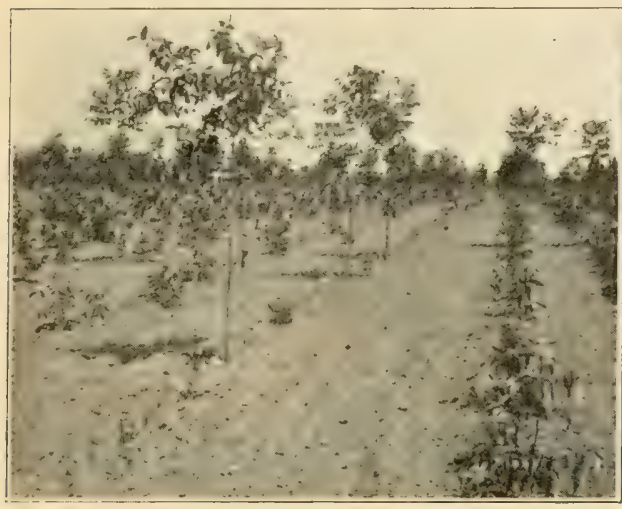

A POOR STAND OF NURSERY GRAFTS (5 PER CENT.)

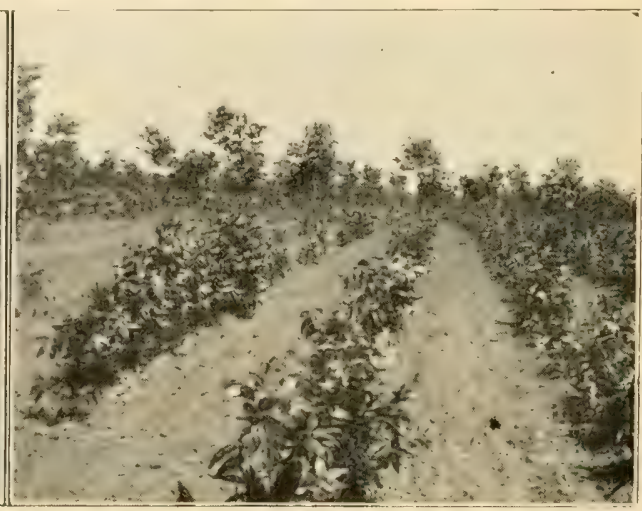

A FAIF STAND OF NURSERY GRAFTS (60 PER CENT.)

rains; (2) sacrifice of nuts from choice bearing trees by the cutting therefrom of scions or budding wood; (3) temporary disfigurement of seedling trees where grafts or buds fail to take; (4) the great care and attention necessary by the propagator the first season after the respective operations; (5) the fact that the stocks must be (with us) two years or more old; (6) that whole roots must be used.*

Permanency. - In horticulture (for profit), as in all other business matters, the best generally proves to be the cheapest, especially where permanent results are desired. A Pecan tree lives to an indefinite age (300 to 700 years), and gen-

* Many fruit trees can be produced by using short sections of the seedling root upon which to graft, as can the apple; not so with the Pecan. 
eration after generation will enjoy the fruits of what we are now planting, therefore plant the best you can get and leave a permanent monument of your good judgment.

Good Stock, Why it Should be Planted. - This covers an important feature of the Pecan industry. The following plan is advocated as being the most reasonable and rational where seedling groves are planted, whether the trees are intended to be subsequently budded or grafted or not. Only seedlings grown from choice nuts, the products of trees of vigorous growth and prolific annual bearers, should be planted, even if they cost a little more than the common seedling, for the following reasons: (I) A certain variable percentage of seedlings raised from selected nuts may reasonably be expected to produce better nuts than if raised from inferior ones; (2) the next best thing to a gentine budded or grafted tree of a well-tested variety is a seedling from a good nut; (3) the influence (if any) of a seadling from a good nut on a bud or graft is likely to be more beneficial than prejudicial; (4) the nuts from good seedlings are usually profitable, whereas if very small Pecans, pig nuts, hickories or allied stocks of inferior varieties be used, and not subsequently budded or grafted with choice Pecans, the product of such seedling trees may be practically worthless. By far the greater number of our buds and grafts are put on Magnum Bonum, Egg Shell, Stevens, Bacon's Choice and No. I Commercial seedling stocks, all produced in our own groves of cultivated trees and we consider that we are doing our utmost to produce trees of the highest possible grade.

Saving Expenses. - Where one can not afford to plant a grove entirely of budded and grafted trees, the better plan is to plant scedlings grown from choice nuts, at the same time to buy twenty per cent. of budded or grafted trees of the choicest varieties, from which subsequently to get scions and buds. Good budding or grafting wood is difficult to obtain and is very expensive as with fine nuts at their present price the cutting of buds and scions means the sacrifice of many pounds of nuts selling at anywhere from 5oc. to \$3.00 per pound. Therefore, where seedlings are planted, it behooves everyone to forestall this difficulty by having their own budded or grafted trees of choice varieties and subsequently to convert all seedlings into specific varieties, which can be done any time after seadlings have become well established in their permanent place and have commenced to grow vigorously. 


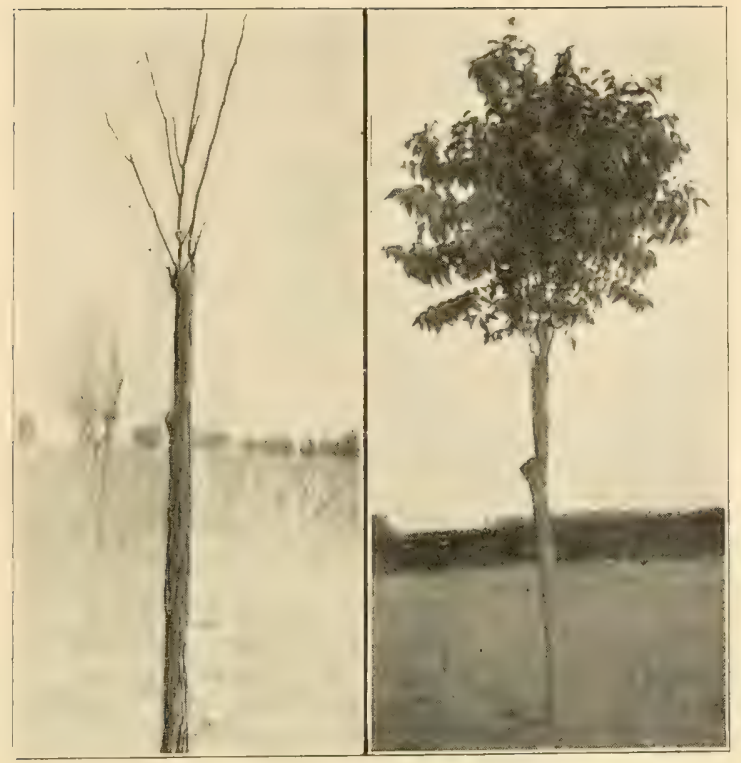

1.

(1) CLEFT GRAFTS IN 5 YEAR SEEDLING STOCK. (ONE YEAR'S GROWTH.) FEBRUARY, 1904.
2.

TIIE SAMIE TREE MAY, 1904.

The second or third year after transplantation would perhaps be the best time to bud or graft. Budding will be found generally more satisfactory than grafting; trees can be budded anywhere above the ground, either on the main trunk, or, if they have branched, each branch may be budded.

\section{Disappointment Inevita:}

ble. There will be many dis. appointments in Pecans to those who have planted the "cheapest" trees they could b $11 \mathrm{y}$ without investigating source or variety of trees or reliability of party selling them. As an instance, pig nut trees, represented as choice Pecan trees, have been sold. It will be heart-breaking to those who have planted such trees, relying upon them to support them in their old age, to find they have been swindled and all hope of rest and peace in their declining years vanished. Men will die and leave "Pecan" groves of this kind to their widows and children -with what result?

"Live and Win."-As compared to life insurance, as an investment, everything is in favor of a Pecan grove. After the investment is once made there are no premiums to be paid for you can rent out the land, or farm, or truck on it yourself, and you do not have to die to reap the benefits. The following from the Atlanta Semi-Weekly Joumal, of August 24th, I900, on this subject, is well worth reading:

"The premium on a life insurance policy of $\$ 5,000$ invested in a Pecan grove will soon earn annually an amount equal to the face of the policy and annual increase. Parents and guardians of children will find in this industry safaty, surety of annual incomes throughout life, which can be reached by no other investments. In the Southern States are thousands of acres, so-called "worn out," that will grow Pecans under cultivation, as the roots of these trees feed 
upon soils not reached by other tree-roots and soon can be made to pay a handsome income where now such lands only grow taxes. Investigation will furnish proof of all we have said of the valuable industry, the value of which is beyond the figures we have yet stated in the public prints."

Inferior Trees Expensive- In the +th Annual Report of the Horticultural Society of Missouri (I9OI), appears an article by Albert Brownwell, Northwest Horticulturist, upon the subject of "cheap trees." It is replete with so much truth and common sense that it may be read with profit by all concerned. It reads

"It costs more to produce a good article than a poor one, and in buying. the first question should be not how cheap but how good it is. Many people understand this well enough, and yet how few ever stop to apply the rule to nursary stock. In no other kind of purchase is the quality of the article of such vital importance as in nursery stock. The price of a tree is the smallest part of its cost by the time it has come into bearing. If a man buys cheap trees, to save a few cents on each, by the time the tree comes into bearing the expense of the land, labor, etc., has amounted to several times the cost of the tree; and consequently if his cheap stock turns out, as it uniformly does, to be of inferior and worthless varieties, then it is a serious loss to him and he has to begin all over again. Now, is it not plain to all that it is rank folly for anyone to risk this dead loss of trees, use of land for years, expense of cultivating, etc., to save a few cents on the tree, when for a trifling increase in price he can get the very best warranted stock? As a matter of insurance a man can not afford to buy anything but the best warranted stock. It is a general rule, which can be relied on, that "cheap" stock is worthless stock, and therefore dear at any price. If a man won't pay for good stock, and buys cheap stock in order to save money, he is very sure to lose all he puts into it. Most of the worthless stock is worked off by strange agents, who sell on their own account and are not authorized by any responsible firm to take orders for them. Such men buy up refuse stock from large nurseries for almost nothing and fill their orders with it, claiming it to be good. They also frequently warrant the stock, but as they are unknown or irresponsible, their warranty is absolutely worthless. If people would buy only from agents who can show 


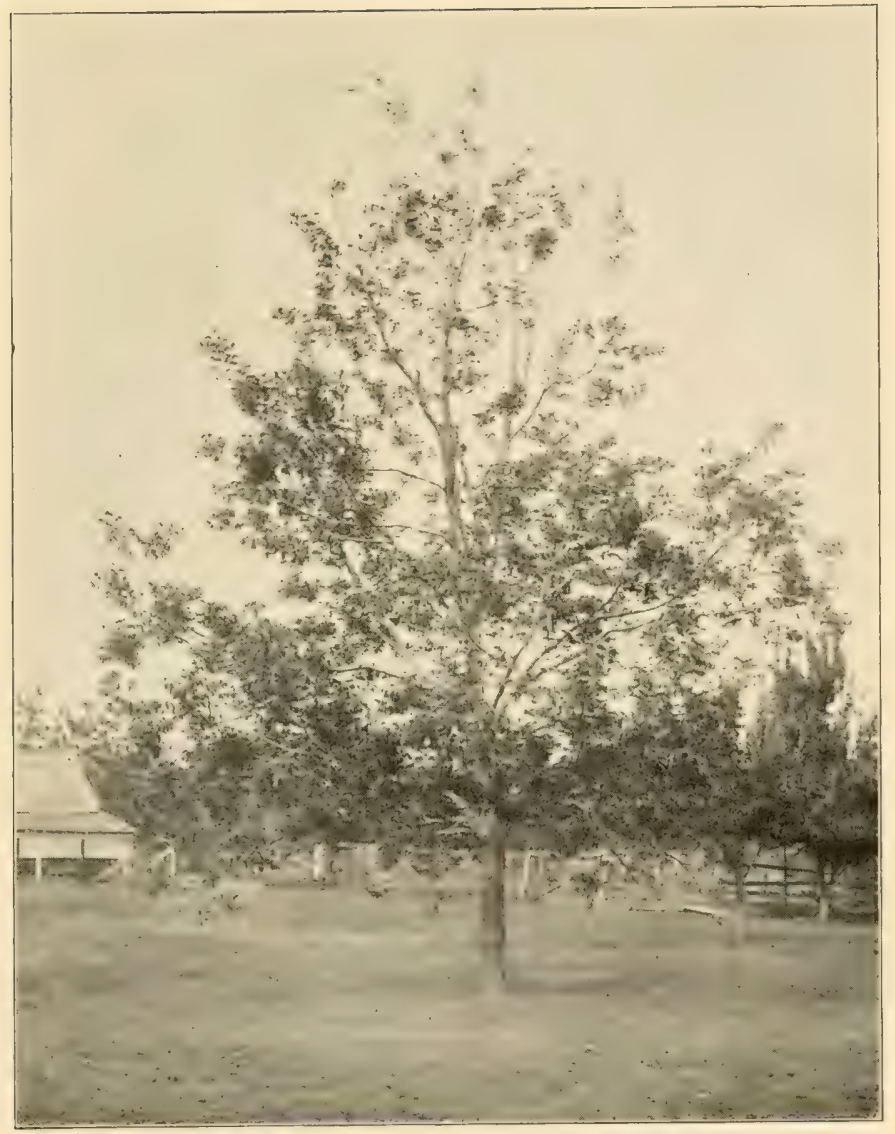

THE PARENT "ATLANTA" TREE, DE WITT, GA. PIIOTO. TAKEN IN APIIL, 1904, BEFORE FOLIAGE FULLY DEVELOPED.

a certificate authorizing them to represent a responsib le firm, there would be no danger of being cheated. WE CAN NOT GET SOMETHING FOR NOTIIIXG.

"This is not a world whicre we can get something for nothing, and when an article is offerer! at an extraordinarily low price, there must be some good reason for it. The very simple reason is that as the article is of bad quality it can not be sold in competition with first-class goods, and is therefore necessarily worked off on the public at a low rate to catch those jeople who will bite at anything cheap, without regard to quality. Such people never get ahzad because they waste their money on poor trash that gives them no "value received' for their outlay."

Japanese Ualnuts. - We are offering Japanese Walnut trees (Juglans Sicboldiana) raised from nuts from our own trees. This nut while not as good as the English or Persian Walnut, is of commercial value. The tree is of rapid growth, begins to bear nuts, in clusters of from seven to fifteen, at three and four years from seed. The meat is sweet. The foliage is very handsome and the trees, being of relatively dwarf habits, may be planted $25 \times 25$ feet. 
Chestnuts.-We have several bearing trees, and after some years of experimental work have evolved a chestnut of very large size and good quality, ripening the last week in July. The nut has been submitted to many compecent judges and is declared to be of great merit. We will propagate it by budding and grafting or sell scions and buds. Budded or grafted trees will not be ready for sale or distribution until fall of 1905 , when prices will be furnished on application.

As to Dealers. - Dealers purchasing from us sell on their own responsibility. We likewise disclaim any liability for results arising from defective planting, or at improper seasons, or from subsequent faulty fertilization and cultivation.

Guarantee.-We guarantee all stock sent out to be well-rooted and properly packed. Our liability under all circumstances is limited in amount to the original price received.

How to Send Money. --Send money the most convenient way, but do not send currency in mail, unless registered. We prefer P. O. or express money orders, or New York Exchange.

Time of Payments. - Unless by special agreement, all payments are positively cash in advance. Mail orders for future delivery should be accompanied by one-fourth cash as a guarantee of good faith.

How to Write Orders. - Always use onr regular order blanks for making up orders, both for your convenience and ours. If for any reason you have no blanks, write the order on separate sheet of paper. Be sure your name and P. O. address is plainly written and shipping directions plainly given.

Responsibility in Transportation.--IThen we take clean receipt from railway or express companies, our responsibility is at an end. We are not responsible for any claims that may arise from then on. We make no charges for packing, package or cartage. All prices are F. O. B., unless by special agreement.

Payments.-Make all paper payable to The G. MI. Bacon Pecan Co. Inc.

\section{NO SAN JOSE SCALE.}

Our nurseries are annually inspected by the Georgia State Entomologist, copy of whose certificate accompanies every shipment of trees. The fumigation of all nursery stock with hydrocyanic acid gas is carried out in a scientific inanner under our personal supervision. 


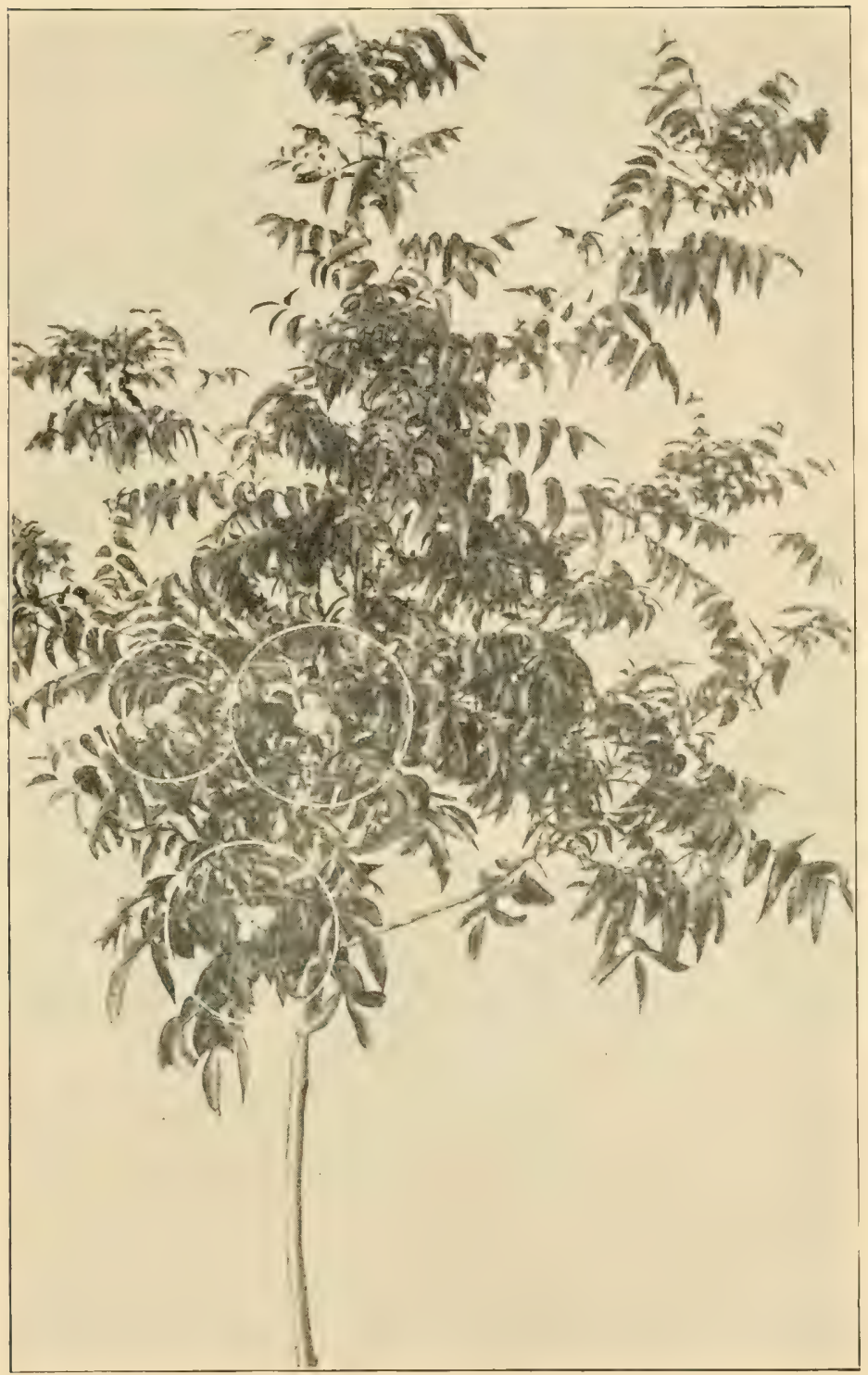

FOUR-YEAR-OLD "GEORGIA GIANT" BUDDED TREE. TREE IN BEARING.

13 NUTS VISIBLE (WITHIN CIRCLES). 11 OTHERS OBSCURED

BY FOLIAGE. DEWITT, GA. 


\section{UARIETIES.}

As selected nuts of the best varieties of Pecans command a ready sale at from $\$$ I.OO to $\$ 3.00$ per pound, parties writing for specimens are requested to enclose five cents for each nut desired.

\section{Georgia Giant.}

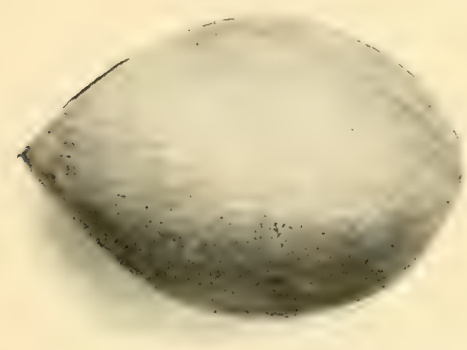

The nut is large, ovate-oblong in shape, thin shell, full-meated and of superior flavor. At five years of age the parent tree bore thirty-two nuts, weighing one pound. It was set out (a one-year seedling) in $\mathrm{I} 886$, and commenced bearing in $189 \mathrm{I}$ and has borne heavy and increasing crops every year. The tree stands on a hard red clay slope, surrounded by other Pecan trees at a distance of only thirty feet. On account of its early, annual and heavy-bearing characteristics and the large size of its nut, it is regarded as probably the best of all the large standard varieties.

\section{Centennial.}

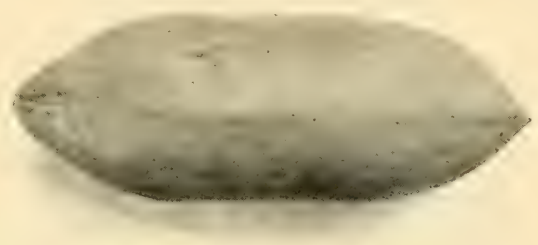

One of the oldest improved varieties. Nut large, pointed at both ends; shell thin; kernel plump. The parent tree is believed to have been grafted fifty years ago.

\section{Stuart.}

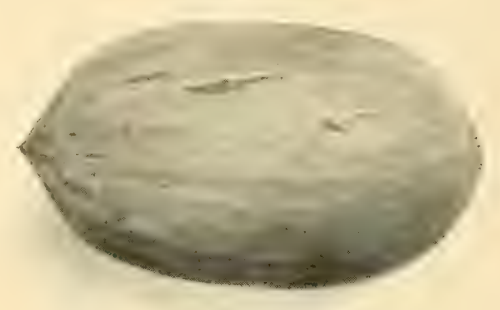

One of the oldest and best tested named varieties. Ovoid in shape; shell thin; kernel plump. A popular variety of demonstrated value and excellence. An early and heavy bearer. Rapid grower. 


\section{Uan Demam.}

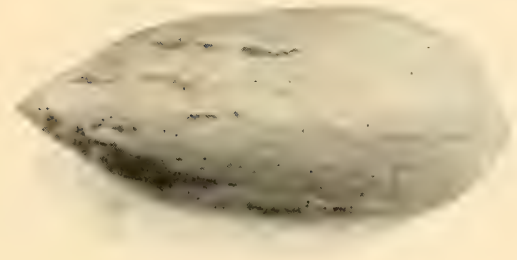

Large nut, oblong in shape, pointed at apex; shell thin. A popular variety.

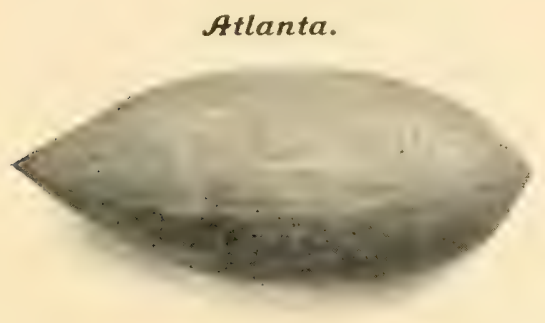

Medium size, oblong, pointed, shell thin. Parent tree is growing in Bermuda pasture; soil very poor and sandy.

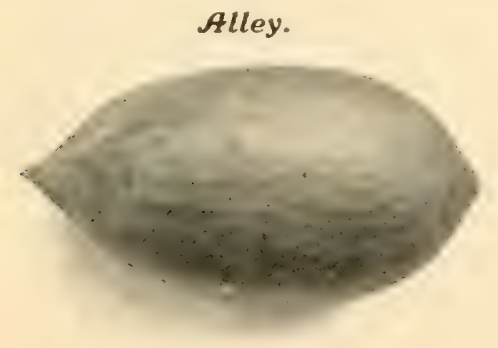

A medium to large nut, oblong-ovoid in shape; very thin shell; full-meated, same of which should be in every grove.

\section{Mammoth. (Renamed "Monarch")}

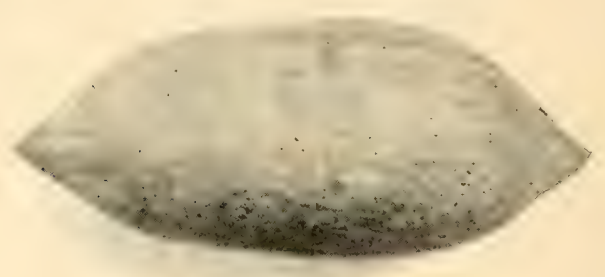

This nut frequently grows to $2^{\mathrm{T} / 2}$ inches in length and $I$ inch in diameter. The parent tree stands on a poor sand ridge sodded in Bermuda grass. This variety is a good bearer and of a remarkably rapid and vigorous growth, making it especially desirable for quickest possible shade, combined with large nuts:

\section{Senator.}

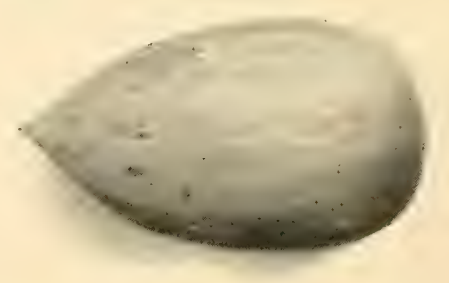

Above medium size; ovate in shape; shell thin; kernel full and plump. This variety is richer in oil than any other variety tested. The parent tree has outgrown all other trees in a I5acre grove and at $I 7$ years old had a spread of 45 feet and height of 65 feet. 


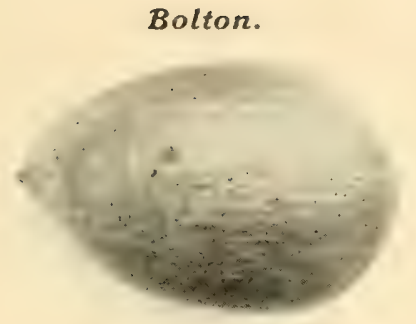

A medium-sized nut of excellent flavor and quality. A popular Florida variety.

\section{Magnum Bonum.}

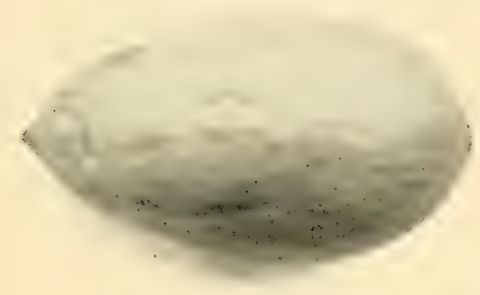

Large nut, oblong-ovate in shape, thin shell and fine flavor.

\section{Erotscher Egg Shell.}

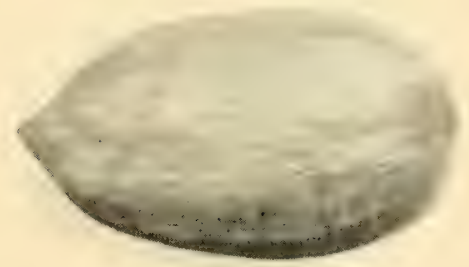

This is a very popular and welltested variety. Nut large, oblongovoid in shape, thin shell.
Majestic.

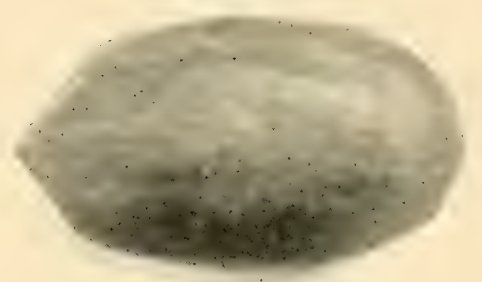

The same as Frotscher Egg Shell. A large, thin-shelled nut of good quality.

\section{Rome.}

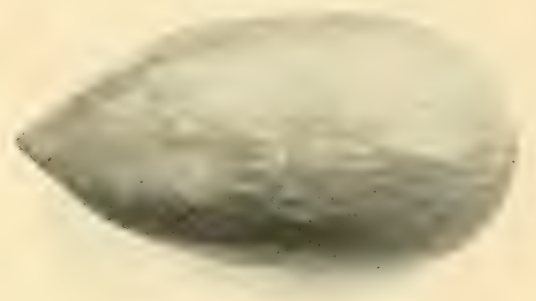

This variety is believed to be identical with the "Columbian" and "Pricle of the Coast." It is one of the largest Pecans known. Shape, round at one end, pointed at the other.

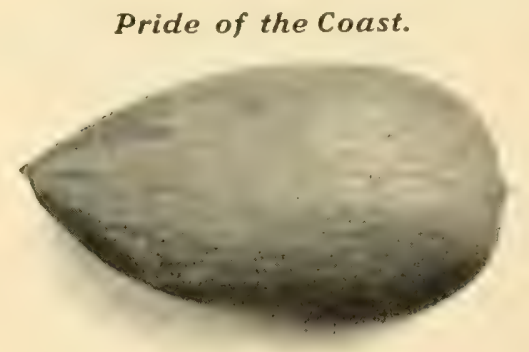

Description same as "Rome." 


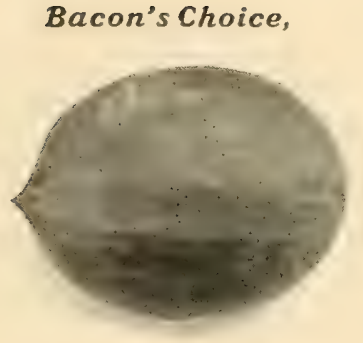

Medium size, slightly ovate, flattened toward the apex. Shell thin, partitions thin, kernel plump, meat of delicious flavor. A very vigorous grower.

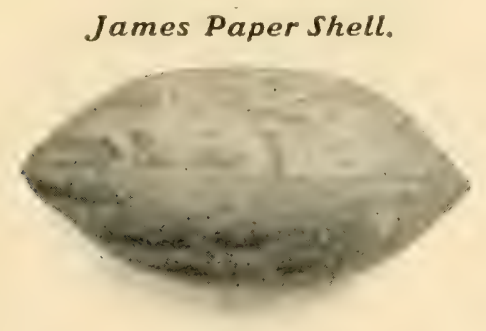

A medium size, very thin-shelled nut of fine flavor.

\section{Stevens.}

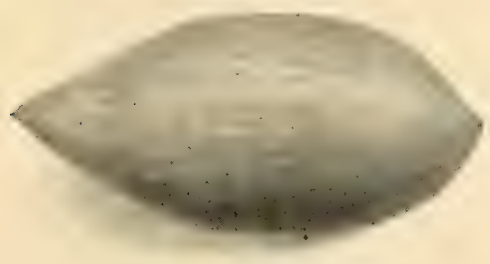

Named for Hon. O. B. Stevens, Commissioner of Agriculture, State of Georgia. Medium size, elliptical in shape. Thin shell and full of rich meat.

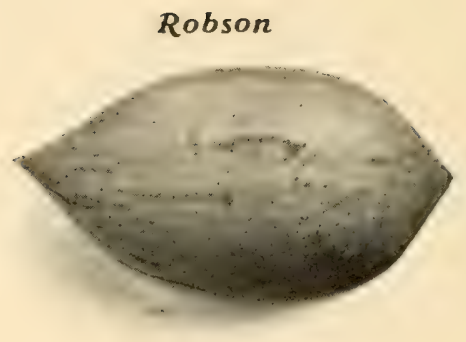

A meditum-sized, very thin-shelled nut, oblong-ovoid in shape. A comparatively new vąriety, but of considerable merit.

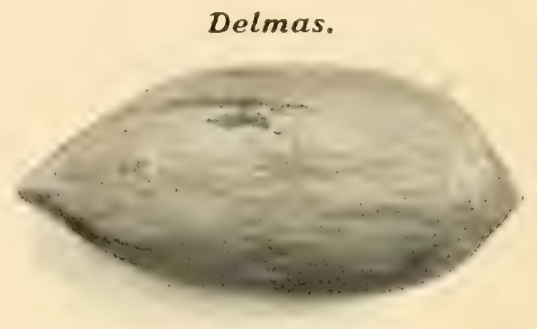

A large nut, pointed at both ends; of excellent quality and vigorous growth.

\section{Capital.}

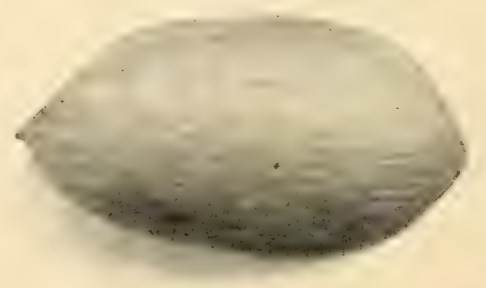

A large, handsome nut, oblongovoid in shape, bearing much resemblance to the "Columbian," "Rome," and "Pride of the Coast." 


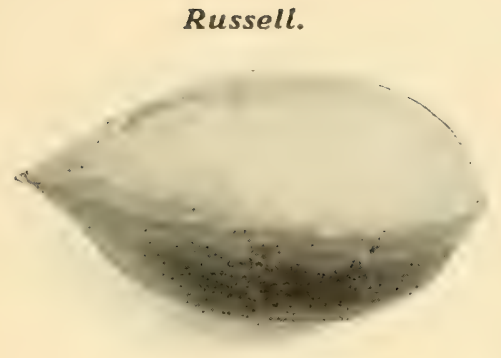

A well-known variety of good quality and very thin shell.

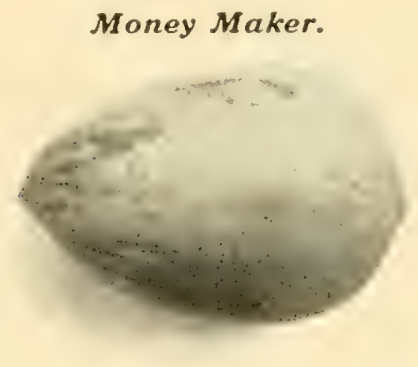

A large nut of good quality and good flavor.

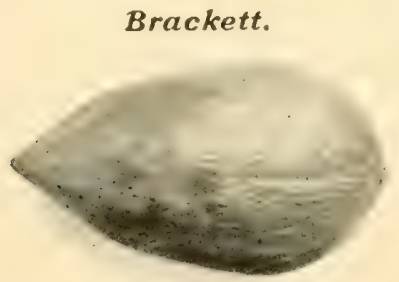

Ovate in shape, thin shell. Trees are fine growers and heavy bearers.
Bartow.

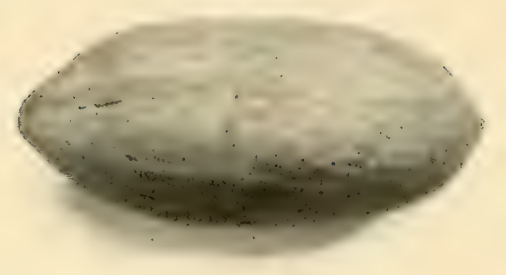

Medium size. Thin shell and fine flavor.

\section{Pabst.}

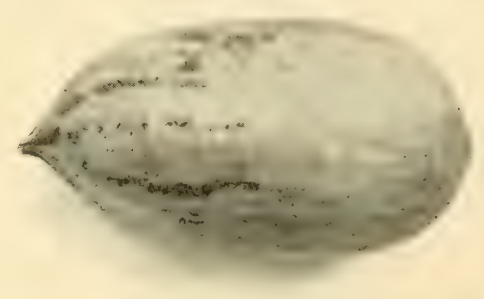

A large nut, oblong-ovate in shape; very closely resembling the "Magnum Bonum."

\section{Egg Shell.}

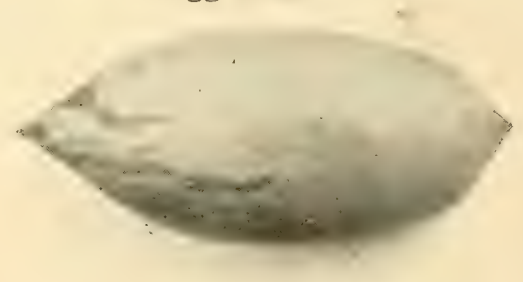

Medium size, thin shell. Fine flavor and a good bearer. 
Admiral Schley.

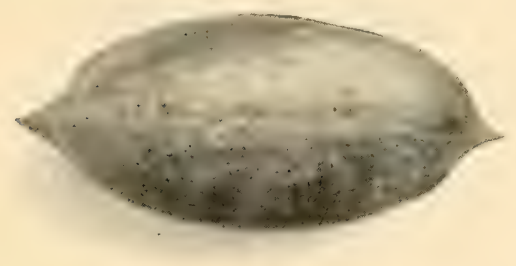

A very thin-shelled variety and deservedly becoming very popular.

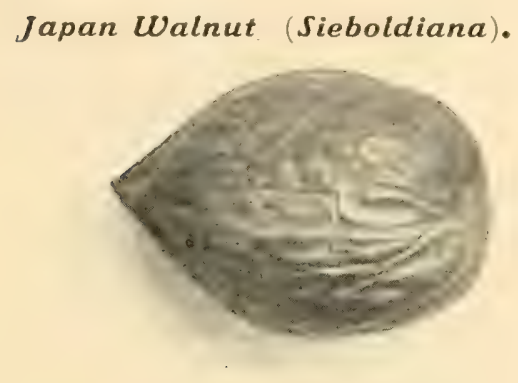

A hardy tree of magnificent foliage, handsome form and early-bearing; comes true to seed.

\section{Columbian.}

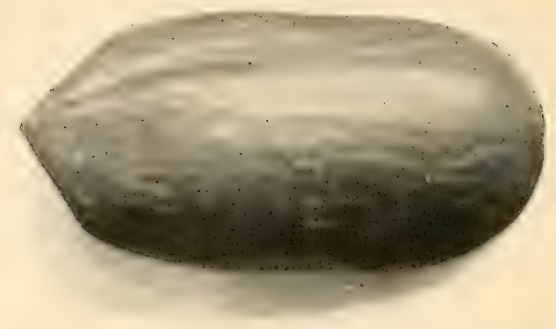

Description same as "Rome."

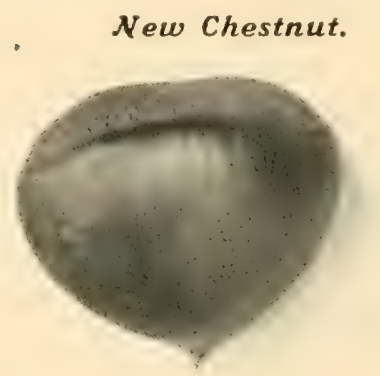

A new chestnut originating at De Witt, Ga. Heavy bearer; foliage bright and free from rust. Ripens in latter part of July. Vigorous growers.

Notr.-In conformance with the rules of the American Pomological Society and the National Nut Growers' Association, which rules are designed to simplify the nomenclature of fruits and nuts by eliminating double as well as hyphenated names, it is our intention to change the name of the "Georgia Giant" to "Georgia" (Synonym Georgia Giant,) the "Mangum Bonum" to "Mangum" (Synonym Mangum Bonum,) the "Bacon's Choice" to "Bacon" (Synonym Bacon's Choice) and the "Mammoth" to "Monarch" (Synonym DeWitt Mammoth,) the names of our other varieties remaining unchanged. We have not changed the names in this catalogue as our numerous customers are used to and familiar with the old names and misunderstanding or confusion might result. 


\section{PRICE LIST. \\ Budded and Grafted Pecan Trees.}

Georgia Giant, Admiral Schley, Frotscher Egg Shell, MIanmoth, Van Deman, Centennial, Stuart, Egg Shell, Capital, Atlanta, Stevens, Robson, Rome, Senator, Pabst, Russell, James Paper Shell, Money Maker, Pride of the Coast, Bolton, Bartow, Bacon's Choice, Majestic, Magnum Bonum, Alley, Delmas, Columbian.

Inches.

Each. Per Doz. Per Ioo.

\begin{tabular}{|c|c|c|c|}
\hline 6-10 & 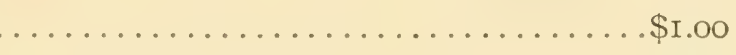 & $\$ 12.00$ & $\$ 80.00$ \\
\hline $10-20$ & 1.50 & I 5.00 & IOO.00 \\
\hline-30 & . I I.75 & I8.00 & I 25.00 \\
\hline-40 & 2.00 & 21.00 & I 50.00 \\
\hline $40-60$ & 2.50 & 24.00 & 175.00 \\
\hline
\end{tabular}

60 and over

The above varieties are grafted and budded upon exceptionally good seedling Pecan stocks, and no pig nuts, hickories, or other inferior allied stocks are used by us. The nuts from which our stocks are grown are for the most part raised from Magnum Bonum, Egg Shell, Bacon's Choice, Stevens, and No. I Commercial seedlings, all raised in our own groves.

\section{Choice Seedling Trees From Nuts of Specific Uariety.} (Raised from muts from large, healthy, early-bearing, vigorous trees, and especially recommended as being next in value to budded and grafted trees).

Mammoth, Atlanta, Stevens, Senator, Bacon's Choice, Brackett, Magnum Bonum, Egg Shell, and Georgia Giant.

Sizes,

Each. Per io. Per ioo. Per rooo.

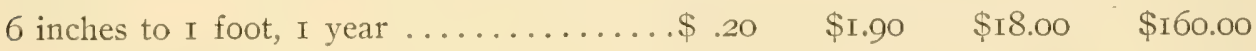

I foot to 2 feet, I year ................ $25 \quad 2.35 \quad 22.50 \quad 200.00$

2 feet to 3 feet, 2 years $\ldots \ldots \ldots \ldots \ldots \ldots . .50 \quad 4.75 \quad 45.00 \quad 400.00$

3 feet to 4 feet, 3 years $\ldots \ldots \ldots \ldots \ldots \ldots .75 \quad 7.10 \quad 67.50 \quad 600.00$

4 feet and over, 3 years ............. I.00 9.50 $90.00 \quad 800.00$

Note. - We always carry extra large trees rumning from 6 to 10 feet in height for special purposes or where parties want extra large trees for yard or lot planting. We carry them in budded, grafted and seedling trees. 
Separate and distinct from our seedling trees of specific varieties (above named), and to fill the demands of the trade and large growers, we plant each year many thousands of pounds of nuts, produced in our own cultivated orchards, and keep a large stock of trees always on hand to supply nurserymen, and others. We offer well-grown, thrifty Pecan seedlings one, two, three and four years old at the following prices:

Sizes.

Per I00. Per I,000.

6 in, to I foot, I year .................... \$ 8.00

$\$ 75.00$

I to 2 feet, I year ............................. I0

90.00

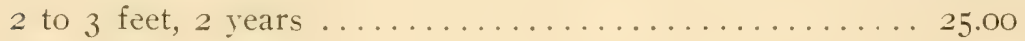

225.00

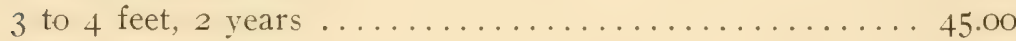

360.00

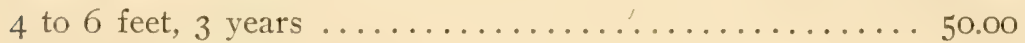

450.00

6 to 8 feet and over, 4 years .................... 55.00

475.00

The large size trees are very desirable for getting a grove started quickly. All these seedlings make most excellent stocks upon which to bud and graft. Special prices on large orders quoted upon application.

\section{Japan Walnuts.}

Sizes.

(Juglans Sieboldiana.)

6 inches to 2 feet, I year ................ \$ .25

2 feet to 3 feet, 2 years .................... 30

Per io. Per Ioo.

3 feet to 4 feet, 3 years .................. 50

$\$ 2.40 \quad \$ 22.50$

$2.85 \quad 27.00$

4 feet to 5 feet, 3 years ................... 75

$4.75 \quad 45.00$

$7.10 \quad, 67.50$

\section{Number of Trees to the Acre.}

Distance Apart-feet.

No. of Trees.

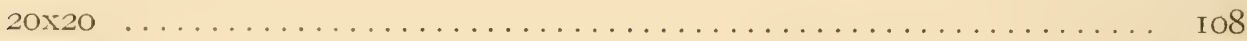

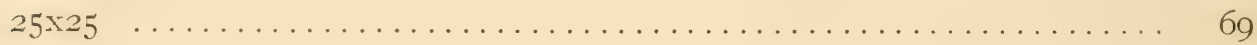

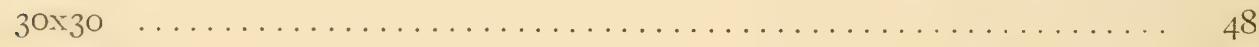

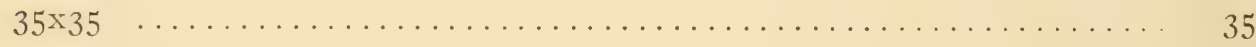

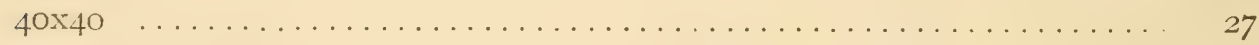

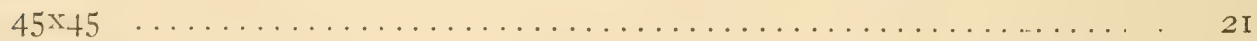

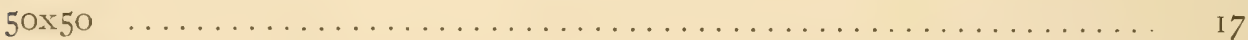

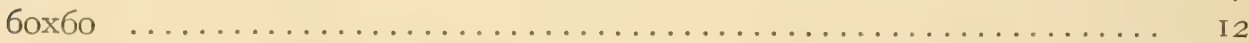

Rule for Ascertaining the Number of Trees Required for One Acre of Land.

Multiply the distance in faet between the rows by the distance the trees are to be apart in the row, and the product will be the number of square feet for each tree, which divided into 43,560 (the number of feet in an acre), will show how many trees the acre will contain. 



\section{The PECAN TREE}

How to Plant It

How to Grow It

How $t o, B$ ur 16

She G. M. BACON PLCAN CO, Inc. DeWitt, - Miechell County,-Georgitis

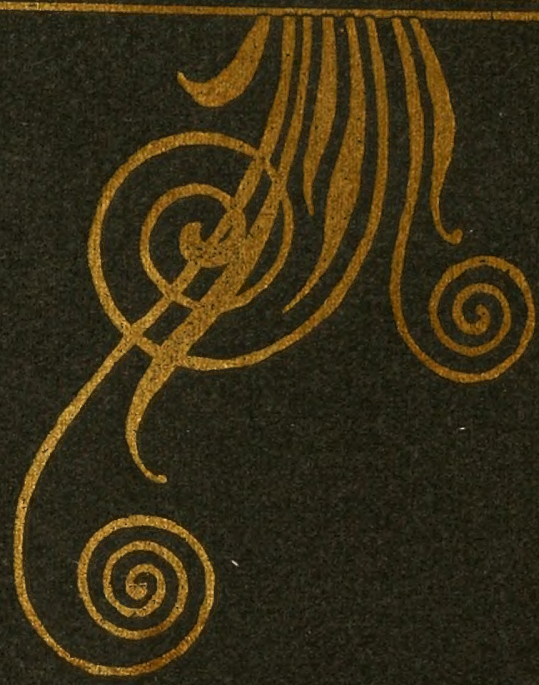


LIBRARY OF CONGRESS

|||||||||||||||||||||||||||||||||||||||||||||

Miminaminain

00009188642 